\title{
Scrutinizing surface glycoproteins and poxin-schlafen protein to design a heterologous recombinant vaccine against monkeypox virus
}

Syeda Farjana Hoque ${ }^{a, b}$, Md. Nazmul Islam Bappy ${ }^{a}$, Anjum Taiebah Chowdhury ${ }^{a}$, Md. Sorwer Alam Parvez ${ }^{c}$, Foeaz Ahmed $^{a}$, Md. Abdus Shukur Imran ${ }^{a, b}$, Kazi Faizul Azim ${ }^{a, d}$, Mahmudul Hasan ${ }^{a, b}$

a Faculty of Biotechnology and Genetic Engineering, Sylhet Agricultural University, Sylhet-3100, Bangladesh

${ }^{b}$ Department of Pharmaceuticals and Industrial Biotechnology, Sylhet Agricultural University, Sylhet-3100, Bangladesh

${ }^{c}$ Department of Genetic Engineering and Biotechnology, Shahjalal University of Science and Technology, Sylhet-3114, Bangladesh

${ }^{d}$ Department of Microbial Biotechnology, Sylhet Agricultural University, Sylhet-3100, Bangladesh

\section{*Corresponding author:}

Mahmudul Hasan

Assistant Professor

Department of Pharmaceuticals and Industrial Biotechnology

Sylhet Agricultural University, Sylhet-3100, Bangladesh

E-mail: mhasan.pib@sau.ac.bd

Telephone: +8801723698461 


\title{
Scrutinizing surface glycoproteins and poxin-schlafen protein to design a heterologous recombinant vaccine against monkeypox virus
}

\begin{abstract}
Monkeypox is a zoonotic disease caused by monkeypox virus with noteworthy mortality and morbidity. Several recent outbreaks and the need of dependable reconnaissance have raised the level of concern for this developing zoonosis. In the present study, a reverse vaccinology strategy was developed to construct a peptide vaccine against monkeypox virus by exploring cell surface binding protein, Poxin-Schlafen andenvelope protein. Both humoral and cell mediated immunity induction were the main concerned properties for the designed peptide vaccine. Therefore, both $\mathrm{T}$ cell and $\mathrm{B}$ cell immunity against monkeypox virus were analyzed from the conserver region of the selected protein. Antigenicity testing, transmembrane topology screening, allergenicity and toxicity assessment, population coverage analysis and molecular docking approach were used to create the superior epitopes of moneypox virus. The subunit vaccine was constructed using highly immunogenic epitopes with appropriate adjuvant and linkers. Molecular docking examination of the refined vaccine with various MHCs and human immune receptor illustrated higher binding interaction. The designed construct was reverse transcribed and adjusted for $E$. coli strain $\mathrm{K} 12$ earlier to inclusion inside pET28a $(+)$ vector for its heterologous cloning and expression. The study could start in vitro and in vivo studies concerning effective vaccine development against monkeypox virus.
\end{abstract}

Keywords: Monkeypox; recombinant vaccine, surface binding protein; poxin-schlafen protein; envelope protein 


\section{Scrutinizing surface glycoproteins and poxin-schlafen protein to design a heterologous recombinant vaccine against monkeypox virus}

\section{Introduction}

The destruction of smallpox was one of the most noteworthy accomplishments within the history of public wellbeing. One of the awful incongruities of this victory is the rise of Monkeypox (MPX) with noteworthy mortality and morbidity (Ladnyj et al., 1972). The later clear increment in human monkeypox cases over a wide geographic range, the potential for advance spread, and the need of dependable reconnaissance have raised the level of concern for this developing zoonosis (Durski et al., 2018). Monkeypox could be a smallpox-like viral contamination caused by an infection of zoonotic beginning, which has a place to the sort Orthopoxvirus, family Poxviridae, and sub-family Chordopoxvirinae.

Monkeypox infection could be a large and double stranded DNA virus (Damon, 2011). The symptoms of the monkeypox are similar like the clinical symtoms of smallpox. It contain various types of clinical presentation which include fever, back pain,characteristic rash, headache and flulike symptoms (Pal et al., 2017).Transmission of monkeypox is accepted to happen by means of respiratory excretions or outside fabric or contact with injury exudate. Viral shedding through feces may speak to another introduction source (Jezek et al., 1988; Hutson et al., 2009). Human monkeypox was first found in Congo in 1970 (Arita et al., 1985; Marennikova et al., 1972). Human monkeypox may be a sporadic illness which was caused by MPV transmission from creatures to people within the tropical rainforest districts of Central and Western Africa and it was examined from 1981 to 1986. Approximately $28 \%$ of the cases were caused by secondary human to human spread. On the other hand, tertiary and quaternary transmissions of virus were uncommon (Ježek et al., 1988). Almost 388 of the 418 recorded cases of human monkeypox happened in Zaire from 1970 to 1995 (Breman, 2000). Human monkeypox cases were surpassed and it was 500 in 1996 and 1997. A few hundred modern cases were found by DRC wellbeing specialistsin January 1999 (Mukinda et al., 1997; Breman, 2000).

The suspension of general vaccination within the 1980s has given rise to expanding defenselessness to monkeypox infection within the human. Monkeypox has continuously been considered an uncommon intermittent malady with a restricted capacity to spread between people (WHO, 1984). It was one of the life-threatening illness within the Law based Republic of the Congo (DRC) and other nations of western and central Africa (Meyer et al., 2002). The recognizable proof of monkeypox in 3 isolated patients within the United Kingdom (UK) in September raised media and political consideration on a rising open wellbeing risk. As of 13th October 2018, there have been 116 affirmed cases, the larger part of which was beneath forty years old (Petersen et al., 2019). The risk would increment in the event that there would be a destructiveness increment (Blumberg and Lloyd-Smith, 2013; Jackson et al., 2001), a infection spill into more broadly conveyed taxa ( Reynolds et al., 2012) or an presentation in other landmasses (Rimoin et al., 2010). Thus, monkeypox has a place to the biosafety level 3, the "high threat" biodefence level within the EU (Tian et al., 2014). The mortality rate of monkeypox (10\%) lies between the mortality rate of variola minor(1\%) and variola major (30\%). Monkeypox is an endemic disease in the Democratic Republic of the Congo. The virus was also imported once into the USA (Sklenovská et al., 2018). 
There are no authorized treatments to treat human monkeypox virus untill 2019.Dryvax, a smallpox vaccine were used for both smallpox and monkeypox treatment (Hammarlund et al., 2005). Both vaccine and persons in contact with the vaccine were influenced by the various negative effects (CDC, 2001; CDC, 2003). Monkeypox infection disease of sound rhesus macaques shows up to be a reasonable demonstrate to think about defensive resistant reactions against monkeypox (Hooper et al., 2004). Undoubtedly, macaques inoculated with Dryvax are ensured from monkeypox (Edghill-Smith et al., 2003; Earl et al., 2004; Hooper et al., 2004; Edghill-Smith et al., 2005).Later information have appeared that the major mode of security from monkeypox managed by the current non-attenuated smallpox immunization is intervened by Abs (Edghill-Smith et al., 2005). Exhaustion of either CD4 T cells or CD8 T cells in inoculated creatures some time recently monkeypox infection challenge does not influence survival, though B cell exhaustion some time recently and amid immunization abrogates vaccine-induced assurance. In like manner, passive administration of vaccinia infection (VACV) 3 Abs confers assurance from subsequent deadly monkeypox (Edghill-Smith et al., 2005). Hence, next-generation smallpox vaccination may not ought to be based on duplicating vectors, given that they evoke appropriate $\mathrm{Ab}$ reactions. The definition of VACV defensive Ags has been constrained by the complexity of the VACV proteome that encodes a few 200 proteins. In any case, proteins L1R and A27L, particular to the intracellular develop infection (IMV), and proteins $\mathrm{A} 33 \mathrm{R}$ and $\mathrm{B} 5 \mathrm{R}$, particular to the extracellular encompassed infection (EEV), have been appeared to be immunogenic and ensured mice from VACV (Fogg et al., 2004; Galmiche et al., 1999; Hooper et al., 2000). As of late, security from monkeypox-induced extreme infection was too watched taking after gene gun immunizations with as it were four VACV DNA plasmids encoding these four proteins (Hooper et al., 2004). In this way, smallpox vaccines based on recombinant peptides ought to be able to bestow security from monkeypox.

Hence, it is necessary to invent the suitable polyvalent vaccine against monkeypoxvirus. Genomics and proteomics study of drug has a great wing to design drugs by utilizing in-silico study. In-silico study is also necessary for immunoinformatics approach, reducing cost and time in development process of drug (Hasan et al., 2019a; Adhikari et al., 2018; Mohammed et al., 2017; Dash et al., 2017). Different genome based innovations have empowered practically dazzle choice of vaccine candidates and permitted expectation of antigens without the necessity to develop the pathogen in vitro (Rappuoli, 2000; Sette and Fikes, 2003; Agrawal and Raghava, 2018). Subsequently, we in this connected a few bioinformatics database, tools and computer program to plan a thermostable and profoundly immunogenic, multi-epitope peptide vaccine against Monkeypox virus utilizing their preserved locale protein arrangements.

\section{Materials and Methods}

In the present study, reverse vaccinology approach was used to design a novel multiepitope subunit vaccine against monkeypox virus requiring effective medications and preventive measures. The flow chart summarizing the entire protocol of in silico strategy for developing a vaccine has been illustrated in Figure 01. 


\section{Retrieval of protein sequences and antigenicity screening}

The ViralZone (https://viralzone.expasy.org/search?query=monkeypox) and National Center for Biotechnology Information (NCBI) server were used for the comprehensive study and selection of monkeypox virus proteins (https://www.ncbi.nlm.nih.gov/genome/?term=monkeypox). Three proteins (Cell surface binding protein, Poxin-Schlafen, Envelope protein A28 homolog) were selected on the basis of their antigenicity by using VaxiJen v2.0 (http://www.ddg-pharmfac.net/vaxijen/) (Doytchinova and Flower, 2007a). ProtParam tool was used for the analysis of their various types of physicochemical properties (Gasteiger et al., 2003).

\section{Identification of homologous proteins sets}

Homologous sequences of the antigenic proteins (i.e. Cell surface-binding protein, Poxin-Schlafen, Envelope protein A28 homolog) in different monkeypox strain were retrieved from the NCBI database by using BLASTp tool. Proteins were used as query and the searches were restricted to Monkeypox virus (taxid:10244), Monkeypox virus Zaire-96-I-16 (taxid:619591), Monkeypox virus (strain Sierra Leone 70-0266) (taxid:130669), Monkeypox virus (strain Zaire 77-0666) (taxid:130670).

\section{Identification of conserved regions and T-cell epitope prediction}

Clustal Omega server was used for Multiple sequence alignment (MSA) (Chenna et al., 2003; Sievers and Higgins, 2014), as well as encourage those common locales were utilized for T-Cell epitopes expectation (Vita et al., 2014). T cell epitope prediction server (http://tools.iedb.org/main/tcell/) of IEDB were utilized to predict the $\mathrm{T}$ cell epitope (MHC-I and MHC-II).

\section{Transmembrane topology and antigenicity screening of T-Cell epitope}

Prediction of transmembrane topology of proteins was performed via TMHMM (http://www.cbs.dtu.dk/services/TMHMM/) tool. Antigenicity of the conserved fragments were determined via VaxiJen v2.0 server (http://www.ddg-pharmfac.net/vaxijen/) (Krogh et al., 2001; Doytchinova and Flower, 2007b). The foremost potent antigenic epitopes were chosen and permitted for advance investigation.

\section{Population coverage, allergenicity and toxicity analysis of predicted epitopes}

HLA dispersion changes in diverse geographic spaces and ethnic social orders in the whole earth. IEDB population coverage calculation server (http://tools.iedb.org/population/) was used for population coverage study (Vita et al., 2014). In addition, four servers named AllergenFP (http://ddg-pharmfac.net/AllergenFP/), AllerTOP (http://www.ddg-pharmfac.net/AllerTop/), Allermatch (http://www.allermatch.org/ allermatch.py/form) and Allergen Online (http://www.allergenonline.org) were utilized to foresee the allergenicity of the proposed epitopes for immunization development (Dimitrov et al., 2014; Dimitrov et al., 2013; Fiers et al., 2004 ) whereas toxicity was predicted by using ToxinPred tool (http://crdd.osdd.net/raghava/toxinpred/) (Gupta et al., 2013).

\section{Conservancy analysis of MHC restricted alleles}

Conservancy investigation server (http://tools. iedb.org/conservancy/) was chosen for conservancy investigation at IEDB server. In this case, protein BLAST was done with antigenic proteins which was picked from the NCBI database. 


\section{Identification of B-Cell epitope}

B-Cell epitopes were identified by using IEDB server. In this case, 3 several algorithms are used and those are: Bepipred Linear Epitope Prediction 2.0, Emini surface accessibility prediction and Kolaskar and Tongaonkar antigenicity scale (Jespersen et al., 2017; Emini et al., 1985; Kolaskar and Tongaonkar, 1990).

\section{Construction of vaccine molecules}

Three vaccine constructs (i.e. V1, V2 and V3) were built. Different adjuvents like beta defensin (a 45 mer peptide); HABA protein (accession number: AGV15514.1; $M$. tuberculosis) and L7/L12 ribosomal protein were used in this purpose after the best CTL epitopes, best HTL epitopes and BCL epitopes individually(Rana and Akhter, 2016). Other sequence like PADRE as well as diverse linker like GGGS, EAAAK, KK and GPGPG were utilized too for developing of potential vaccine against monkeypox virus.

\section{Allergenicity, antigenicity and solubility prediction of various vaccine constructs}

Four tools named AllergenFP, AllerTOP, Allermatch and Allergen Online were utilizedfor determining the non-allergic nature of the constructed vaccine. To determine the most potent vaccine, antigenicity and the solubility of the suggested vaccine were determined via VaxiJen v2.0 and via Proso II tool respectively (Doytchinova and Flower,2007b; Smialowski et al., 2006).

\section{Physicochemical characterization and secondary structure analysis}

ProtParam , a tool provided by ExPASy server (Hasan et al., 2019b; Azim et al., 2019a) was used to functionally characterize (http://expasy.org/cgibin/protpraram) (Gasteiger et al., 2003) the vaccine proteins. Isoelectric $\mathrm{pH}$, aliphatic index, molecular weight, instability index, estimat half-life, hydropathicity, GRAVY values, and other physicochemical characteristics were studied. Through GOR4 secondary structure prediction method, alpha helix, beta sheet and coil structure of the vaccine constructs were determined by the Prabi tool (https://npsa-prabi.ibcp.fr/).

\section{Structure predictio, validation and disulfide engineering of vaccine constructs}

RaptorX server was used for constructing 3D model of vaccine. This step is necessary for knowing the percentage of sameness between template structure and target protein and those were collected from RCSB PDB (Peng and $\mathrm{Xu}, 2011$ ). Vaccine structure was validated by Ramachandran plot assessment at RAMPAGE (Hasan et al., 2015). Disulfide bonds was designed by $\mathrm{DbD} 2$ server for anticipated vaccine constructs (Craig and Dombkowski, 2013).

\section{Protein-protein docking}

Patchdock tool was used for molecular docking between HLA alleles and the predicted vaccine constructs. The tool leveled the docked compounds based on complementarity score, ACE (Atomic Contact Energy) and approximate interface area of the compound. On the basis of free binding Energy, results showed that V1 vaccine was the superior. V1 construct also docked with various human immune receptors (TLR 2, TLR 4,TLR 9). Highest binding affinity between vaccine construct and receptor were detected by the lowest binding energy of the complexes. 


\section{Codon adaptation and in silico cloning}

Codon adaptation was carried out via JCAT tool to speed up the expression of construct V1 in E. coli strain K12. In this case, various restriction enzymes (i.e. BglI and BglII), prokaryote ribosome-binding site and Rho independent transcription termination were kept away from the work (Grote et al., 2005). Than mRNA sequence of constructed V1 vaccine was conjugated with BglI and BglII restriction site at the C-terminal and N-terminal sites respectively. In this case, SnapGene was used for the cloning purpose (Solanki \& Tiwari, 2018).

\section{Result}

\section{Retrieval of protein sequences and antigenicity screening}

The full viral proteome of monkeypox virus (Proteome ID: UP000101269) was collected from UniProtKB (https://www.uniprot.org/uniprot/?query+database). Most potent antigenic protein was found from the VaxiJen server. Among three viral proteins, cell surface binding protein (Accession ID: Q8V4Y0.) and Poxin-Schlafen (Accession ID: Q8V4S4) and Envelope protein A28 homolog ( Accession ID: Q8V4U9) were identified, having better immunogenic potential with total prediction score of $0.5311,0.4753$ and 0.6212 respectively. Various types of physiochemical properties of proteins are given in Table 01 .

\section{Retrieval of homologous protein sets and identification of conserved regions}

Three several homologous protein of monkeypox virus were created after BLASTp via NCBI BLAST server. Different homologous protein sets for each protein were generated after BLASTp search using NCBI BLAST tools. A total of 6, 4 and 10 conserved pieces were found among the cell surface binding protein, envelope protein A28 homolog and poxin-Schlafen protein respectively (Table 02).

\section{Antigenicity prediction and transmembrane topology analysis of the conserved fragments}

4,4,5 conserved framents were selected from cell surface binding protein, envelope protein A28 homolog and poxin-Schlafen proteins respectively because of their VaxiJen level is upper than their default threshold level (Table 02). On the other hand, transmembrane topology server showed that, from the immunogenic conserved sequences 5, 1 and 6 sequences from the corresponding proteins fulfilled the property of exomembrane characteristics (Table 02).

\section{Prediction of T-cell epitope, transmembrane topology and antigenicity screening}

A large number of epitops were created from the conserved sequences which could bind with highest number of HLA cells with maximum binding affinity. After analysis their antigenicity score and transmembrane topology, top epitopes of the selected three proteins were screened (Table 03). Epitopes with a positive higher value of immunogenicity showed potential to evoket effective T-cell response. 


\section{Population coverage, allergenicity and toxicity analysis of predicted epitopes}

Popultion coverage were done for all three proteins with their both MHC class I and MHC class II . From the screening, populationof thevarious geographic areas can be covered by the predicted T-cell epitopes.results of population coverage of three several viral proteins are shown in Figure 2. AllerTOP, AllergenFP, Allergen online, Allermatch servers were used for allergenicity screening. Non-allergen epitopes for human were selected (Table 03). Allergen and toxic epitopes were removed from the predicted list (Table 03).

\section{Epitope conservancy analysis}

Cell surface binding protein, poxin-Schlafen and envelope protein were found to be exceedingly moderated inside diverse strains of monkeypox infection with most noteworthy conservancy level of $93 \%$ (Table 01 ). The rate of conservancy chowed that, epitopes were organically noteworthy.

\section{Identification of B-Cell epitope}

Three algorithms (i.e. Bepipred Linear Epitope prediction, Emini Surface Accessibility, Kolaskar \& Tongaonkar Antigenicity prediction) were used for screeninf of B-cell epitopes of cell surface binding protein, poxin-Schlafen and envelope protein from IEDB. Further screening of selected epitopes were done by analysis their antigenicity scoring and allergenicity (Table 04).

\section{Vaccine molecule construction}

Total three vaccines (V1, V2 and V3) were constructed (Table 05). Each vaccine construct contain a protein adjuvent, T-cell, B-cell epitopes and epitope's linkers. PADRE sequence was added to increase the potency and efficacy of the constructed vaccine.The designed vaccine constructs V1, V2 and V3 were 323, 407 and 348 residues long.

\section{Allergenicity, antigenicity and solubility prediction of different vaccine constructs}

All 3 constructs (V1, V2 and V3) were non-allergenic (Table 05). All of them, V1 showed the best result with solubility score (0.657) (Figure 3 ) and antigenicity (0.6547).

\section{Physicochemical characterization and secondary structure analysis}

Physicochemical properties of V1 construct were analyzed through ProtParam tool. Molecular weight of V1 construct showed superior immunity and it was scored $34.879 \mathrm{kDa}$. The extinction coefficient was 52830 at $0.1 \%$ absorption, assuming all cysteine residues are lowed. The theoretical pI 9.75 recommended that the protein will have net negative charge which is higher than this pI. The approximated half-life was decided to be one hour within mammalian reticulocytes in vitro while greater than ten hours in E. coli in vivo. Thermostability and hydrophilic nature of the protein were presented by the aliphatic index and GRAVY value which were 62.26 and -0.619 respectively. Secondary structure of the predictedt V1 vaccine construct confirmed to have $27.24 \%$ alpha helix, $23.84 \%$ sheet and $48.92 \%$ coil structure. 


\section{Prediction, validation and disulfide engineering of vaccine constructs}

V1 vaccine constructs was composed by using RaptorX server (Figure 04). Ramachandran plot analysis was used during validation process where $90.9 \%$ residues were in the favored, $7.2 \%$ residues in the allowed and $1.9 \%$ residues in the outlier region (Figure 04). 3D structure of V2, V3 vaccine were constructed (Figure 05). There were 33 pairs of amino acid residue were recognized which have the potentiality to create disulfide bond by DbD2 server. After analysis chi3 and B-factor parameter of residue pairs on the basis of energy, only two pairs (GLY 21-ARG47 and LYS245-SER250) fulfill the property for disulfide bond development which were changed with cysteine. The value of energy was considered less than 2.5 and chi3 value for the residue screening was between -87 to +97 (Figure 06).

\section{Protein-protein docking}

The affinity between HLA alleles and the constructed vaccines (V1, V2 and V3) were analyzed using molecular docking via Patchdock tool. The affinity between V1 construct and human immune receptors were determined also (Figure 07). The server leveled the docked compounds based on complementarity score, Atomic Contact Energy (ACE) and approximate interface area of the complex. All of them, V1 vaccine construct showed the superior in terms of free binding Energy (Table 07). Highest binding affinity between vaccine construct and receptor were indicated by ther lowest binding energy of the complexes.

\section{Codon adaptation and in silico cloning}

The Codon Adaptation Index for the optimized codons of construct V1 was 0.967 determined via JCAT server. The GC content of the adapted codons was also significant (46.23\%). An insert of 986 bp was obtained which lacked restriction sites for BglII and BglI ensuring, thus ensuring safety for cloning purpose. The codons were inserted into $\mathrm{pET} 28 \mathrm{a}(+)$ vector along with BgIII and BgII restriction sites and a clone of 4564 base pair was produced (Figure 08).

\section{Discussion}

Monkeypox virus (MPX) has recently focused global media, political and scientific attention after the identification in the United Kingdom (UK) in September 2018 of 3 separate patients diagnosed with monkeypox (PHE, 2018). Though it causes disease in humans with symptoms similar, but less severe, to those previously seen in smallpox (WHO, 2019), the extremely infectious virus is often responsible for severe systemic lesional disease in humans and noteworthy auxiliary spread of infection inside near communities. Along these lines, it is imperative to require preventive measures against it. Generally, live-attenuated or inactivated forms of microbial pathogens have been utilized for induction of antigen-specific responses that prevent the host against secondary infections (Thompson \& Staats, 2011). But only 10 of a few hundred proteins are used for vaccine development and it depends on the microbes (Li et al., 2014). However, all of the protein is not necessary for protective immunity, whereas only few selective proteins are used (Tesh et al., 2002). On the other hand, those unnecessary proteins are responsible for allergenic reactions. So it is crying need to remove all of those protein from the vaccine formulations (Petrovsky \& Aguilar, 2004). There were no licensed therapies to treat human monkeypox viral infection (Pal et al., 2017) until 2019. Few days ago, FDA accepted a vaccine called JYNNEOS which is a non-replicating and live vaccine for the avoidance of 
monkeypox virus. Be that as it may, no security concerns that would require a Medication Guide were determined (ANALGESICS, 2019). The foremost common $(>10 \%)$ antagonistic responses related with JYNNEOS were infusion location reactions. Itching, swelling, pain, induration, redness, are the common side effects of this vaccine. There are also some systemic adverse reactions also which are headache, nausea, muscle pain, fatigue, chills and myalgia. Genuine antagonistic responses were detailed in $0.05 \%$ of subjects who gotten JYNNEOS and included sarcoidosis, throat tightness, Crohn's malady and extraocular muscle paresis. Cardiac unfavorable responses of extraordinary intrigued were detailed in $0.08 \%$ of subjects who gotten JYNNEOS and added electrocardiogram $T$ wave inversion, electrocardiogram $\mathrm{T}$ wave abnormal, electrocardiogram ST segment elevation, palpitation and electrocardiogram abnorma (Bavarian-nordic, 2019). ST-246 is an anti orthopoxvirus compound that extremely potent, inhibiting orthopoxvirus replication in vitro at $\mathrm{nM}$ concentrations (Duraffour et al., 2007; Quenelle et al., 2007; Yang et al., 2005). after injection of ST-246, lesions are created and weight is also lost (Grosenbach et al., 2008). For these reasons, it is necessary to develop subunit vaccines which contain one or few selective proteins of pathogens in vaccine construction for induction of protective immunity (Petrovsky \& Aguilar, 2004; Thompson et al., 2011). However, this can create an attention towards "peptide vaccines". This vaccine contains only epitopes able to induce positive, desirable $\mathrm{T}$ cell and B cell mediated immune response (Sesardic, 1993). To activate humoral and cellular responses, these peptides are considered adecuate for activation (Bijker et al., 2007; Lin et al., 2013), whereas killing allergenic and/or reactogenic reactions.

Ordinary approaches for vaccine advancement are not continuously attainable as pathogens are some of the time troublesome to develop and in a few occurrences to constrict coming about in unpleasant or antagonistic immune reactions (Purcell et al., 2007; Azim et al., 2019b). Propels in genomics have altered the concepts and presently, it is conceivable to utilize genomic based approaches to help determination and structure based plan of vaccine candidates (Ahluwalia et al., 2017). Reverse vaccinology, a novel process to combine immunogenetics and immunogenomics with in-silico study has been utilized massively to present modern vaccines (Hasan et al., 2019c; Poland et al., 2009). In this study, we pointed to plan an epitope based peptide vaccine against monkeypox through immunoinformatics procedures by using different bioinformatics database and servers. To the finest of our information such genome based immunoinformatic process has not be used however to create a multiepitope vaccine with wide run viability. The full monkeypox virus proteome was collected from UniProtKB and the physiochemical characteristics of the proteins were examined. The VaxiJen tool was utilized to survey the antigenicity of all the recovered protein arrangements in arrange to discover out the foremost potent antigenic protein. Among the three monkeypox proteins, ell surface binding protein, Poxin-Schlafen, Envelope protein A28 homolog were recognized as the finest immunogenic protein candidates and permitted for advance investigation. All the proteins are selected on the basis of antigenicity. Since antigenicity has been utilized to depict both the capacity of the antigen to combine with the antibody conjointly its capacity to induce antibody creation (Rao, 1972). These proteins have necessary function in membrane fusion, recognition by host immune machinery and receptor binding (Oster, 2016). Envelope proteins of monkeypox virus has specificity for adding to human cells (Maa et al., 1990). Poxin is a nuclease enzyme that is conserved in mammalian poxviruses (Eaglesham et al., 2019). Poxin is preserved in mostvirus within the class Orthopoxvirus, counting the human pathogens monkeypox infection and cowpox infection, and is in some cases combined to an extra C-terminal space to have homology with human schlafen proteins (Liu et al., 
2018). Two eminent exemptions to preservation of poxin action are Variola major infection, the causative specialist of smallpox malady, and the adjusted vaccinia Ankara (MVA) immunization strain, which both appear inactivation of poxin (Eaglesham et al., 2019). Preservation of poxins between mammalian infections and creepy crawlies reaffirms the hereditary roots of 2',3'-cGAMP-dependent flagging in creatures, and underscores the wide extend of host-virus clashes that drive modern components of intrinsic safe reconnaissance and avoidance (Kranzusch et al., 2015). To guarantee defensive reaction against a longer run of infection strains for a longer period, the selected epitopes must stay within the profoundly conserved locale. For this, only the conserved sequences are used for epitope recognition. In this study, we believe that, we can create a universally effective and more acceptable vaccine constructs. Assurance of potent T cell epitopes could be a urgent step amid vaccine design, since T-cells play the key part in antibody generation through antigen introduction. T cell epitopes identification is the major step at the time of vaccine design. Moreover, T-cells play the key role in antibody production through antigen presentation (Amorim et al., 2016). IEDB T cell epitope prediction server was used for predicting both MHC class I (CTL) and MHC class II restricted (HTL) epitopes. Transmembrane topology screening, allergenicity pattern, antigenicity scoring, toxicity profile and conservancy analysis were used for selecting top potent epitopes.

The proposed protein appeared a high aggregate population coverage in most of the geographic rlocales counting 92.51\% (MHC-I) and 92.49\% (MHC-II) coverage in North Africa and Australia individually (Fig. 2). The top epitopes were highly conserved among different viral strains extending from $8 \%$ to $91 \%$ (Table 3 ). furthermore, the selected CTL and HTL epitopes were checked for their capacity to tie with MHC-I and MHC-II alleles. B-cell epitopes can boost neutralizing-antibody responses in the host. To realize defensive immunity against monkeypox virus, B-cell (BCL) epitopes were recognized utilizing three distinctive algorithms (i.e. Linear Epitope, Surface Accessibility, Antigenicity) from IEDB (Table 4). Carrier molecules were needed to add adjuvanting and chemical stability to the epitopes, because the size of epitoe is tiny and have weak immunogenicity (Aguilar \& Rodriguez, 2007; Purcel et al., 2007). The selected CTL, HTL and BCL epitopes were added using various linker and adjuvants to design the final constructs. Than the efficiency and safety were recognized (Table 5). It was found that, V1 is the most potent vaccine construct after analysis allergenicity, physicochemical characteristics, hydrophobicity and immunogenicity score. Tertiary structure of the vaccine constructs were determined to strengthen our selection. Moreover, interactions between various HLA molecules (i.e. HLA-DRB1*03:01, HLA-DRB5*01:01, HLA-DRB1*01:01, HLA-DRB3*01:01, HLA-DRB1*04:01 and HLA-DRB3*02:02) and designed vaccine constructs were identified (Table 6). On the basis of free binding energy, V1 vaccine construct was found to be the best. Besides, docking examination was too performed to investigate the binding affinity of develop V1 and distinctive human immune receptors (TLR 2, MyD88, TLR 8) to assess the adequacy of utilized adjuvants (Table 6). Those human immune receptors were identified for the cellular receptor of the monkeypox virus (Schleimann et al., 2019; $\mathrm{Xu}$ et al., 2000; Hutchens et al., 2008). The toll-like receptor 8 (TLR8), is found essentially in endosomes of plasmacytoid dendritic cells and B cells where it identifies non-methylated cytosine-guanine DNA motifs (Kawai \& Akira, 2011; Kapp et al., 2014). At last, the develop V1 was switch deciphered and embedded inside pET28a $(+)$ vector for heterologous expression in E. coli srain K12. Due to the empowering discoveries of the study, we recommend assist wet lab based investigation utilizing show creatures for the exploratory approval of our anticipated vaccine candidates. Additionally, novel antigen 
conveyance frameworks such as Nano-delivery stages might upgrade the viability of the proposed antibody (Hojo 2014; Trovato and Berardinis, 2015).

\section{Conclusion}

In-silico bioinformatics study can be considered as a promising technique to accelerate vaccine improvement against exceedingly pathogenic living beings. Within the display think about, such approach was utilized to plan a novel peptide vaccine against the foremost dangerous monkeypox. The consider proposes, the proposed immunization seem invigorate both humoral and cellular intervened resistant reactions and serve as a potential immunization against monkeypox virus. Be that as it may, in vitro and in vivo immunological tests are exceedingly suggested to approve the adequacy of outlined vaccine constructs.

\section{Funding information}

This research did not receive any specific grant from funding agencies in the public, commercial, or not-for-profit sectors.

\section{Conflict of interest}

The Authors declare that they have no conflicts of interest.

\section{References}

Adhikari UK, Tayebi M, Rahman MM. Immunoinformatics Approach for Epitope-Based Peptide Vaccine Design and Active Site Prediction against Polyprotein of Emerging Oropouche Virus. Journal of immunology research. 2018;2018.

Agrawal P, Raghava GP. Prediction of antimicrobial potential of a chemically modified peptide from its tertiary structure. Frontiers in Microbiology. 2018;9:2551.

Aguilar JC, Rodriguez EG. Vaccine adjuvants revisited. Vaccine. 2007 May 10;25(19):3752-62.

Amorim KN, Rampazo EV, Antonialli R, Yamamoto MM, Rodrigues MM, Soares IS, Boscardin SB. The presence of $\mathrm{T}$ cell epitopes is important for induction of antibody responses against antigens directed to DEC205+ dendritic cells. Scientific reports. 2016 Dec 21;6:39250.

ANALGESICS, O., 2019. New vaccine for smallpox, monkeypox.

Arita I, Jezek Z, Khodakevich L, Ruti K. Human monkeypox: a newly emerged orthopoxvirus zoonosis in the tropical rain forests of Africa. The American journal of tropical medicine and hygiene. $1985 \mathrm{Jul}$ 1;34(4):781-9. 
Azim KF, Hasan M, Hossain MN, Somana SR, Hoque SF, Bappy MN, Chowdhury AT, Lasker T. Immunoinformatics approaches for designing a novel multi epitope peptide vaccine against human norovirus (Norwalk virus). Infection, Genetics and Evolution. 2019 Jun 21:103936.

Azim KF, Lasker T, Akter R, Hia MM, Bhuiyan OF, Hasan M, Hossain MN. Conglomeration of highly antigenic nucleoproteins to inaugurate a heterosubtypic next generation vaccine candidate against Arenaviridae family. bioRxiv. 2019 Jan 1. doi: https://doi.org/10.1101/2019.12.29.885731

Bavarian-nordic. http://www.bavarian-nordic.com/investor/news/news.aspx?news=5758. 2019. Accessed on $15^{\text {th }}$ January, 2020.

Bijker MS, Melief CJ, Offringa R, Van Der Burg SH. Design and development of synthetic peptide vaccines: past, present and future. Expert review of vaccines. 2007 Aug 1;6(4):591-603.

Blumberg S, Lloyd-Smith JO. Inference of R0 and transmission heterogeneity from the size distribution of stuttering chains. PLoS Computational Biology. 2013 May 2;9(5):e1002993.

Breman JG. Monkeypox: an emerging infection for humans?. InEmerging infections 4 2000 Jan 1 (pp. 45-67). American Society of Microbiology.

Centers for Disease Control and Prevention (CDC. Supplemental recommendations on adverse events following smallpox vaccine in the pre-event vaccination program: recommendations of the Advisory Committee on Immunization Practices. MMWR. Morbidity and mortality weekly report. 2003 Apr 4;52(13):282

Centers for Disease Control and Prevention. Vaccinia (smallpox) vaccine, recommendations of the Advisory Committee on Immunization Practices (ACIP), 2001. Mortal Morb Wkly Rep.. 2001;50:1-25.

Chenna R, Sugawara H, Koike T, Lopez R, Gibson TJ, Higgins DG, Thompson JD. Multiple sequence alignment with the Clustal series of programs. Nucleic Acids Res.

Craig DB, Dombkowski AA. Disulfide by Design 2.0: a web-based tool for disulfide engineering in proteins. BMC bioinformatics. 2013 Dec;14(1):346.

Damon IK. Status of human monkeypox: clinical disease, epidemiology and research. Vaccine. 2011 Dec 30;29:D54-9.

Dash R, Das R, Junaid M, Akash MF, Islam A, Hosen SZ. In silico-based vaccine design against Ebola virus glycoprotein. Advances and applications in bioinformatics and chemistry: AABC. 2017;10:11.

Dimitrov I, Bangov I, Flower DR, Doytchinova I. AllerTOP v. 2 - a server for in silico prediction of allergens. Journal of molecular modeling. 2014 Jun 1;20(6):2278. 
Dimitrov I, Naneva L, Doytchinova I, Bangov I. AllergenFP: allergenicity prediction by descriptor fingerprints. Bioinformatics. 2013 Oct 27;30(6):846-51.

Doytchinova IA, Flower DR. Identifying candidate subunit vaccines using an alignment-independent method based on principal amino acid properties. Vaccine. 2007 Jan 15;25(5):856-66.

Doytchinova IA, Flower DR. VaxiJen: a server for prediction of protective antigens, tumour antigens and subunit vaccines. BMC bioinformatics. 2007 Dec;8(1):4.

Duraffour S, Snoeck R, De Vos R, van Den Oord JJ, Crance JM, Garin D, Hruby DE, Jordan R, De Clercq E, Andrei G. Activity of the anti-orthopoxvirus compound ST-246 against vaccinia, cowpox and camelpox viruses in cell monolayers and organotypic raft cultures. Antiviral therapy. 2007 Jan 1;12(8):1205.

Durski KN, McCollum AM, Nakazawa Y, Petersen BW, Reynolds MG, Briand S, Djingarey MH, Olson V, Damon IK, Khalakdina A. Emergence of monkeypox-west and central Africa, 1970-2017. Morbidity and Mortality Weekly Report. 2018 Mar $16 ; 67(10): 306$.

Eaglesham JB, Pan Y, Kupper TS, Kranzusch PJ. Viral and metazoan poxins are cGAMP-specific nucleases that restrict cGAS-STING signalling. Nature. 2019 Feb;566(7743):259.

Earl PL, Americo JL, Wyatt LS, Eller LA, Whitbeck JC, Cohen GH, Eisenberg RJ, Hartmann CJ, Jackson DL, Kulesh DA, Martinez MJ. Immunogenicity of a highly attenuated MVA smallpox vaccine and protection against monkeypox. Nature. 2004 Mar;428(6979):182.

Edghill-Smith Y, Golding H, Manischewitz J, King LR, Scott D, Bray M, Nalca A, Hooper JW, Whitehouse CA, Schmitz JE, Reimann KA. Smallpox vaccine-induced antibodies are necessary and sufficient for protection against monkeypox virus. Nature medicine. 2005 $\mathrm{Jul} ; 11(7): 740$.

Edghill-Smith Y, Venzon D, Karpova T, McNally J, Nacsa J, Tsai WP, Tryniszewska E, Moniuszko M, Manischewitz J, King LR, Snodgrass SJ. Modeling a safer smallpox vaccination regimen, for human immunodeficiency virus type 1-infected patients, in immunocompromised macaques. The Journal of infectious diseases. 2003 Oct $15 ; 188(8): 1181-91$.

Emini EA, Hughes JV, Perlow D, Boger J. Induction of hepatitis A virus-neutralizing antibody by a virus-specific synthetic peptide. Journal of virology. 1985 Sep 1;55(3):836-9.

Fiers, M.W., Kleter, G.A., Nijland, H., Peijnenburg, A.A., Nap, J.P. and Van Ham, R.C., 2004. Allermatch ${ }^{\mathrm{TM}}$, a webtool for the prediction of potential allergenicity according to current FAO/WHO Codex alimentarius guidelines. BMC bioinformatics, 5(1), p.133.

Fogg C, Lustig S, Whitbeck JC, Eisenberg RJ, Cohen GH, Moss B. Protective immunity to vaccinia virus induced by vaccination with multiple recombinant outer membrane proteins of intracellular and extracellular virions. Journal of virology. 2004 Oct 1;78(19):10230-7. 
Galmiche MC, Goenaga J, Wittek R, Rindisbacher L. Neutralizing and protective antibodies directed against vaccinia virus envelope antigens. Virology. 1999 Feb $1 ; 254(1): 71-80$.

Gasteiger E, Hoogland C, Gattiker A, Duvaud S, Wilkins MR, Appel RD. 662 Bairoch A Protein Identification and Analysis Tools on the ExPASy Server. 663. Nucleic Acids Res. 2003;31:3784-8.

Gasteiger E, Hoogland C, Gattiker A, Wilkins MR, Appel RD, Bairoch A. Protein identification and analysis tools on the ExPASy server. InThe proteomics protocols handbook 2005 (pp. 571-607). Humana press.

Grosenbach DW, Jordan R, King DS, Berhanu A, Warren TK, Kirkwood-Watts DL, Tyavanagimatt $\mathrm{S}$, Tan $\mathrm{Y}$, Wilson RL, Jones KF, Hruby DE. Immune responses to the smallpox vaccine given in combination with ST-246, a small-molecule inhibitor of poxvirus dissemination. Vaccine. 2008 Feb 13;26(7):933-46.

Grote A, Hiller K, Scheer M, Münch R, Nörtemann B, Hempel DC, Jahn D. JCat: a novel tool to adapt codon usage of a target gene to its potential expression host. Nucleic acids research. 2005 Jul 1;33(suppl_2):W526-31.

Gupta S, Kapoor P, Chaudhary K, Gautam A, Kumar R, Raghava GP, Open Source Drug Discovery Consortium. In silico approach for predicting toxicity of peptides and proteins. PloS one. 2013 Sep 13;8(9):e73957.

Hammarlund E, Lewis MW, Carter SV, Amanna I, Hansen SG, Strelow LI, Wong SW, Yoshihara P, Hanifin JM, Slifka MK. Multiple diagnostic techniques identify previously vaccinated individuals with protective immunity against monkeypox. Nature medicine. 2005 Sep;11(9):1005.

Hasan M, Azim KF, Begum A, Khan NA, Shammi TS, Imran AS, Chowdhury IM, Urme SR. Vaccinomics strategy for developing a unique multi-epitope monovalent vaccine against Marburg marburgvirus. Infection, Genetics and Evolution. 2019 Jun 1;70:140-57.

Hasan M, Islam S, Chakraborty S, Mustafa AH, Azim KF, Joy ZF, Hossain MN, Foysal $\mathrm{SH}$, Hasan MN. Contriving a chimeric polyvalent vaccine to prevent infections caused by Herpes Simplex Virus (Type-1 and Type-2): an exploratory immunoinformatic approach. Journal of biomolecular Structure and Dynamics. 2019 Aug 9:1-8.

Hasan M, Ghosh PP, Azim KF, Mukta S, Abir RA, Nahar J, Khan MM. Reverse vaccinology approach to design a novel multi-epitope subunit vaccine against avian influenza A (H7N9) virus. Microbial pathogenesis. 2019 May 1;130:19-37.

Hasan M, Hakim A, Iqbal A, Bhuiyan FR, Begum MK, Sharmin S, Abir RA. Computational study and homology modeling of phenol hydroxylase: key enzyme for phenol degradation. Int J Comput Bioinfo In Silico Model. 2015. 2015;4(4):691-8. 
Hojo H. Recent progress in the chemical synthesis of proteins. Current opinion in structural biology. 2014 Jun 1;26:16-23.

Hooper JW, Custer DM, Schmaljohn CS, Schmaljohn AL. DNA vaccination with vaccinia virus L1R and A33R genes protects mice against a lethal poxvirus challenge. Virology. 2000 Jan 20;266(2):329-39.

Hooper JW, Thompson E, Wilhelmsen C, Zimmerman M, Ichou MA, Steffen SE, Schmaljohn CS, Schmaljohn AL, Jahrling PB. Smallpox DNA vaccine protects nonhuman primates against lethal monkeypox. Journal of virology. 2004 May 1;78(9):4433-43.

Hutchens M, Luker KE, Sottile P, Sonstein J, Lukacs NW, Nunez G, Curtis JL, Luker GD. TLR3 increases disease morbidity and mortality from vaccinia infection. The Journal of Immunology. 2008 Jan 1;180(1):483-91.

Hutson CL, Olson VA, Carroll DS, Abel JA, Hughes CM, Braden ZH, Weiss S, Self J, Osorio JE, Hudson PN, Dillon M. A prairie dog animal model of systemic orthopoxvirus disease using West African and Congo Basin strains of monkeypox virus. Journal of General Virology. 2009 Feb 1;90(2):323-33.

Jackson RJ, Ramsay AJ, Christensen CD, Beaton S, Hall DF, Ramshaw IA. Expression of mouse interleukin-4 by a recombinant ectromelia virus suppresses cytolytic lymphocyte responses and overcomes genetic resistance to mousepox. Journal of virology. 2001 Feb $1 ; 75(3): 1205-10$.

Jespersen MC, Peters B, Nielsen M, Marcatili P. BepiPred-2.0: improving sequence-based B-cell epitope prediction using conformational epitopes. Nucleic acids research. 2017 May 2;45(W1):W24-9.

Ježek Z, Fenner F. Human monkeypox. S. Karger AG; 1988.

Jezek Z, Grab B, Szczeniowski MV, Paluku KM, Mutombo M. Human monkeypox: secondary attack rates/Z. Jezek...[et al.].

Kapp K, Kleuss C, Schroff M, Wittig B. Genuine immunomodulation with dSLIM. Molecular Therapy-Nucleic Acids. 2014 Jan 1;3:e170.

Kawai T, Akira S. Toll-like receptors and their crosstalk with other innate receptors in infection and immunity. Immunity. 2011 May 27;34(5):637-50.

Kolaskar AS, Tongaonkar PC. A semi-empirical method for prediction of antigenic determinants on protein antigens. FEBS letters. 1990 Dec 10;276(1-2):172-4.

Kranzusch PJ, Wilson SC, Lee AS, Berger JM, Doudna JA, Vance RE. Ancient origin of cGAS-STING reveals mechanism of universal 2', 3' cGAMP signaling. Molecular cell. 2015 Sep 17;59(6):891-903.

Krogh A, Larsson B, Von Heijne G, Sonnhammer EL. Predicting transmembrane protein topology with a hidden Markov model: application to complete genomes. Journal of molecular biology. 2001 Jan 19;305(3):567-80. 
Ladnyj ID, Ziegler P, Kima E. A human infection caused by monkeypox virus in Basankusu Territory, Democratic Republic of the Congo. Bulletin of the World Health Organization. 1972;46(5):593.

Li W, Joshi M, Singhania S, Ramsey K, Murthy A. Peptide vaccine: progress and challenges. Vaccines. 2014;2(3):515-36.

Lin SY, Cheng CW, Su EC. Prediction of B-cell epitopes using evolutionary information and propensity scales. InBMC bioinformatics 2013 Jan (Vol. 14, No. 2, p. S10). BioMed Central.

Liu F, Zhou P, Wang Q, Zhang M, Li D. The Schlafen family: complex roles in different cell types and virus replication. Cell biology international. 2018 Jan;42(1):2-8.

Maa JS, Rodriguez JF, Esteban M. Structural and functional characterization of a cell surface binding protein of vaccinia virus. Journal of Biological Chemistry. 1990 Jan 25;265(3):1569-77.

Marennikova SS, Šeluhina EM, Mal'Ceva NN, Čimiškjan KL, Macevič GR. Isolation and properties of the causal agent of a new variola-like disease (monkeypox) in man. Bulletin of the World Health Organization. 1972;46(5):599.

Marennikova SS, Šeluhina EM, Mal'Ceva NN, Ladnyj ID. Poxviruses isolated from clinically ill and asymptomatically infected monkeys and a chimpanzee. Bulletin of the World Health Organization. 1972;46(5):613.

Meyer H, Perrichot M, Stemmler M, Emmerich P, Schmitz H, Varaine F, Shungu R, Tshioko F, Formenty P. Outbreaks of disease suspected of being due to human monkeypox virus infection in the Democratic Republic of Congo in 2001. Journal of clinical microbiology. 2002 Aug 1;40(8):2919-21.

Mohammed AA, Hashim O, Elrahman KA, Hamdi A, Hassan MA. Epitope-based peptide vaccine design against Mokola rabies virus glycoprotein $\mathrm{G}$ utilizing in silico approaches. Immunome Res. 2017;13(144):2.

Mukinda VB, Mwema G, Kilundu M, Heymann DL, Khan AS, Esposito JJ. Re-emergence of human monkeypox in Zaire in 1996. The Lancet. 1997 May 17;349(9063):1449-50.

Oster AM, Russell K, Stryker JE, Friedman A, Kachur RE, Petersen EE, Jamieson DJ, Cohn AC, Brooks JT. Update: interim guidance for prevention of sexual transmission of Zika virus-United States, 2016. Morbidity and Mortality Weekly Report. 2016 Apr $1 ; 65(12): 323-5$.

Pal M, Mengstie F, Kandi V. Epidemiology, Diagnosis, and Control of Monkeypox Disease: A comprehensive Review. American Journal of Infectious Diseases and Microbiology. 2017;5(2):94-.

Peng J, Xu J. RaptorX: exploiting structure information for protein alignment by statistical inference. Proteins: Structure, Function, and Bioinformatics. 2011;79(S10):161-71. 
Petersen E, Abubakar I, Ihekweazu C, Heymann D, Ntoumi F, Blumberg L, Asogun D, Mukonka V, Lule SA, Bates M, Honeyborne I. Monkeypox-Enhancing public health preparedness for an emerging lethal human zoonotic epidemic threat in the wake of the smallpox post-eradication era. International Journal of Infectious Diseases. 2019 Jan $1 ; 78: 78-84$.

Petrovsky N, Aguilar JC. Vaccine adjuvants: current state and future trends. Immunology and cell biology. 2004 Oct;82(5):488-96.

Poland GA, Ovsyannikova IG, Jacobson RM. Application of pharmacogenomics to vaccines.

Public Health England 2018. Monkeypox -Latest update https://www.gov.uk/government/news/monkeypox-case-in-england -accessed October 29th 2018.

Purcell AW, McCluskey J, Rossjohn J. More than one reason to rethink the use of peptides in vaccine design. Nature reviews Drug discovery. 2007 May;6(5):404.

Quenelle DC, Prichard MN, Keith KA, Hruby DE, Jordan R, Painter GR, Robertson A, Kern ER. Synergistic efficacy of the combination of ST-246 with CMX001 against orthopoxviruses. Antimicrobial agents and chemotherapy. 2007 Nov 1;51(11):4118-24.

Rana A, Akhter Y. A multi-subunit based, thermodynamically stable model vaccine using combined immunoinformatics and protein structure based approach. Immunobiology. 2016 Apr 1;221(4):544-57.

Rappuoli R. Reverse vaccinology. Current opinion in microbiology. 2000 Oct $1 ; 3(5): 445-50$.

Reynolds MG, Carroll DS, Karem KL. Factors affecting the likelihood of monkeypox's emergence and spread in the post-smallpox era. Current Opinion in Virology. 2012 Jun $1 ; 2(3): 335-43$.

Rimoin AW, Mulembakani PM, Johnston SC, Smith JO, Kisalu NK, Kinkela TL, Blumberg S, Thomassen HA, Pike BL, Fair JN, Wolfe ND. Major increase in human monkeypox incidence 30 years after smallpox vaccination campaigns cease in the Democratic Republic of Congo. Proceedings of the National Academy of Sciences. 2010 Sep 14;107(37):16262-7.

Schleimann MH, Kobberø ML, Vibholm LK, Kjær K, Giron LB, Busman-Sahay K, Chan CN, Nekorchuk M, Schmidt M, Wittig B, Damsgaard TE. TLR8 agonist MGN1703 enhances B cell differentiation and function in lymph nodes. EBioMedicine. $2019 \mathrm{Jul}$ $1 ; 45: 328-40$.

Sette A, Fikes J. Epitope-based vaccines: an update on epitope identification, vaccine design and delivery. Current opinion in immunology. 2003 Aug 1;15(4):461-70.

Sesardic D. Synthetic peptide vaccines. J. Med. Microbiol. 1993;39:241-242. 
Sievers F, Wilm A, Dineen D, Gibson TJ, Karplus K, Li W, Lopez R, McWilliam H, Remmert M, Söding J, Thompson JD. Fast, scalable generation of high-quality protein multiple sequence alignments using Clustal Omega. Molecular systems biology. 2011 Jan $1 ; 7(1)$.

Sklenovská N, Van Ranst M. Emergence of monkeypox as the most important orthopoxvirus infection in humans. Frontiers in public health. 2018;6.

Smialowski P, Martin-Galiano AJ, Mikolajka A, Girschick T, Holak TA, Frishman D. Protein solubility: sequence based prediction and experimental verification. Bioinformatics. 2006 Dec 6;23(19):2536-42.

Solanki V, Tiwari V. Subtractive proteomics to identify novel drug targets and reverse vaccinology for the development of chimeric vaccine against Acinetobacter baumannii. Scientific reports. 2018 Jun 13;8(1):9044.

Tesh RB, Arroyo J, da Rosa AP, Guzman H, Xiao SY, Monath TP. Efficacy of killed virus vaccine, live attenuated chimeric virus vaccine, and passive immunization for prevention of West Nile virus encephalitis in hamster model. Emerging infectious diseases. 2002 Dec;8(12):1392.

The current status of human monkeypox: Memorandum from a WHO Meeting Bulletin of the World Health Organization. Bull World Health Organ. 1984; 62:703-13.

Thompson AL, Staats HF. Cytokines: the future of intranasal vaccine adjuvants. Clinical and Developmental Immunology. 2011 Jul 31;2011.

Trovato M, De Berardinis P. Novel antigen delivery systems. World journal of virology. 2015 Aug 12;4(3):156.

Vita R, Overton JA, Greenbaum JA, Ponomarenko J, Clark JD, Cantrell JR, Wheeler DK, Gabbard JL, Hix D, Sette A, Peters B. The immune epitope database (IEDB) 3.0. Nucleic acids research. 2014 Oct 9;43(D1):D405-12.

World Health Organization. World health statistics overview 2019: monitoring health for the SDGs, sustainable development goals [Internet]. Geneva: World Health Organization; 2019 [citado 23 Abr 2019].

Xu Y, Tao X, Shen B, Horng T, Medzhitov R, Manley JL, Tong L. Structural basis for signal transduction by the Toll/interleukin-1 receptor domains. Nature. 2000 Nov;408(6808):111.

Yang G, Pevear DC, Davies MH, Collett MS, Bailey T, Rippen S, Barone L, Burns C, Rhodes G, Tohan S, Huggins JW. An orally bioavailable antipoxvirus compound (ST-246) inhibits extracellular virus formation and protects mice from lethal orthopoxvirus challenge. Journal of virology. 2005 Oct 15;79(20):13139-49. 


\section{Tables}

Table 01: Protparam analysis of selectet protein

\begin{tabular}{|l|l|l|l|l|l|l|l|l|}
\hline protein & $\begin{array}{l}\text { Accession } \\
\text { ID }\end{array}$ & $\begin{array}{l}\text { Molecul } \\
\text { ar } \\
\text { weight }\end{array}$ & $\begin{array}{l}\text { Insta } \\
\text { bility } \\
\text { index }\end{array}$ & $\begin{array}{l}\text { Half- } \\
\text { life }\end{array}$ & $\begin{array}{l}\text { Theo } \\
\text { retic } \\
\text { al pI }\end{array}$ & $\begin{array}{l}\text { No. } \\
\text { of } \\
\text { Ami } \\
\text { no } \\
\text { acids }\end{array}$ & $\begin{array}{l}\text { Total } \\
\text { No. of } \\
\text { Atom } \\
\text { s }\end{array}$ & $\begin{array}{l}\text { Estinction } \\
\text { co-efficie } \\
\text { nt }\end{array}$ \\
\hline $\begin{array}{l}\text { Cell surface } \\
\text { binding } \\
\text { protein }\end{array}$ & Q8V4Y0 & $\begin{array}{l}35278.0 \\
2\end{array}$ & 44.95 & $\begin{array}{l}>10 \\
\text { hours }\end{array}$ & 7.77 & 304 & 4953 & 56270 \\
\hline $\begin{array}{l}\text { Envelope } \\
\text { protein A28 } \\
\text { homolog }\end{array}$ & Q8V4U9 & $\begin{array}{l}16403.6 \\
8\end{array}$ & 29.97 & $\begin{array}{l}>10 \\
\text { hours }\end{array}$ & 6.54 & 146 & 2286 & 14440 \\
\hline $\begin{array}{l}\text { Poxin-Schla } \\
\text { fen }\end{array}$ & Q8V4S4 & $\begin{array}{l}57453.7 \\
8\end{array}$ & 39.03 & $\begin{array}{l}>10 \\
\text { hours }\end{array}$ & 7.58 & 503 & 8029 & 76210 \\
\hline
\end{tabular}


Table 02: Identified conserved regions among different homologous protein sets of Cell surface binding protein, Envelope protein A28 homolog and Poxin-Schlafen

\begin{tabular}{|c|c|c|c|}
\hline Protein & Conserved region & Vexigen & $\begin{array}{l}\text { Topolog } \\
\text { y }\end{array}$ \\
\hline \multirow{6}{*}{ 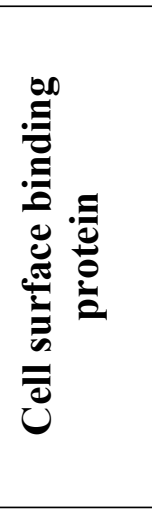 } & MPQQLSPINIETKKAISD & 0.9972 & outside \\
\hline & $\begin{array}{l}\text { RLKTLDIHYNESKPTTIQNTGKLVRINFKGGYISGGFLPNEYV } \\
\text { LSTIHIYWGKEDDYGSNHLIDVYKYSGEINLVHWNKKKYSS } \\
\text { YEE }\end{array}$ & 0.7807 & outside \\
\hline & $\begin{array}{l}\text { KKHDDGIIIIAIFLQVSDHKNVYFQKIVNQLDSIRSANMSAPF } \\
\text { DSVFYLDNLLPSTLDYFTYLGTTINHSADA }\end{array}$ & 0.4468 & outside \\
\hline & WIIFPTPINIHSDQLSKFRTLLSSSNHEGKP & -0.0067 & outside \\
\hline & $\begin{array}{l}\text { YITENYRNPYKLNDDTQVYYSGEIIRAATTSPVRENYFMKW } \\
\text { LSDLR }\end{array}$ & 0.1645 & inside \\
\hline & CFSYYQKYIEGNKTFAIIAIVFVFILT & 0.6078 & outside \\
\hline \multirow{4}{*}{ 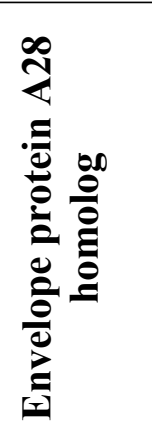 } & $\begin{array}{l}\text { MNSLSIFFIVVATAAVCLLFIQSYSIYENYGNIKEFNATHAAF } \\
\text { EYSKSIGGTPALDRRVQDVND }\end{array}$ & 0.6333 & inside \\
\hline & ISDVKQKWRCVVYPGNGF & 0.9445 & inside \\
\hline & SASIFGFQAEVGPNNT & 0.7511 & outside \\
\hline & $\begin{array}{l}\text { SIRKFNTMRQCIDFTFSDVINIDIYNPCIAPNINNTECQFLKSV } \\
\text { L }\end{array}$ & 0.4689 & inside \\
\hline \multirow{10}{*}{ 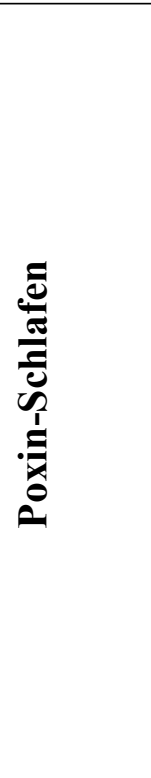 } & MFYAHAFGGYDENLHAFP & 0.2036 & outside \\
\hline & $\begin{array}{l}\text { ISSTVANDVRKYSVVSVYNKKYNIVKNKYMWCNSQVNKR } \\
\text { YIGALLPMFECNEYLQIGDPIHDLEGNQISIVTYRHKNYYAL } \\
\text { SGIGYESLDLCL }\end{array}$ & 0.6140 & outside \\
\hline & GVGIH HHVLETGNAVYGKVQHEYSTIKEKAKEMNA & 0.7427 & outside \\
\hline & $\begin{array}{l}\text { KPGPIIDYHVWIGDCVCQVTTVDVHGKEIMRMRFKRGAVL } \\
\text { PIPNLVKVKVGEENDTINLSTSISALLNSGGGTIEVTSKEERV } \\
\text { DYVLMKRLESIHHLWSVVYDHLNVVNGEERCY }\end{array}$ & 0.5687 & outside \\
\hline & TVKTNLYMKTMGACL & 0.4971 & inside \\
\hline & $\begin{array}{l}\text { MDSMEALEYLSELKESGGRSPRPELQKFEYPDGVKDTESIE } \\
\text { RLAEEFFNRSELQAGESVKFG }\end{array}$ & 0.2660 & outside \\
\hline & SINVKHTSVSAKQLRTRIR & 1.3666 & inside \\
\hline & $\begin{array}{l}\text { QLPSILSSFANTKGGYLFIGVDNNTHKVIGFTVGHDYLKLV } \\
\text { E }\end{array}$ & 0.5208 & outside \\
\hline & DIEKYIQKLPVVHFCKKKEDIKYACRFI & 0.2575 & inside \\
\hline & IKVERCCCAVFADWPESWYMDTSGSMKKYSPDEWVSHIKF & 0.2159 & inside \\
\hline
\end{tabular}


Table 03: Predicted T-cell (CTL and HTL) epitope of Cell surface binding protein, Envelope protein A28 homolog and Poxin-Schlafen

\begin{tabular}{|c|c|c|c|c|c|c|c|c|c|c|}
\hline$\underbrace{\infty}_{0}$ & & Epitope & $\begin{array}{l}\text { STA } \\
\text { RT }\end{array}$ & $\begin{array}{l}\text { EN } \\
\text { D }\end{array}$ & $\begin{array}{l}\text { TOPOL } \\
\text { OGY }\end{array}$ & $\begin{array}{l}\text { VAXI } \\
\text { GEN }\end{array}$ & $\begin{array}{l}\text { NO. } \\
\text { OF } \\
\text { HLA } \\
\text { CEL } \\
\text { L } \\
\end{array}$ & $\begin{array}{l}\text { Allergeni } \\
\text { city }\end{array}$ & $\begin{array}{l}\text { Conser } \\
\text { vancy }\end{array}$ & Toxicity \\
\hline \multirow{17}{*}{ 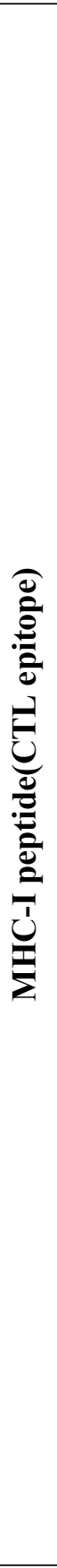 } & \multirow{10}{*}{ 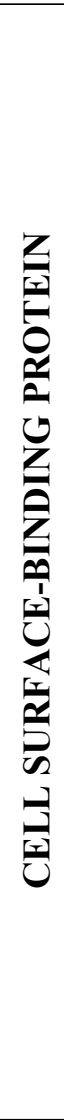 } & $\begin{array}{l}\text { LSTIHI } \\
\text { YWG }\end{array}$ & 44 & 52 & Outside & $\begin{array}{c}1.669 \\
1\end{array}$ & 27 & $\begin{array}{l}\text { Non } \\
\text { Allergen }\end{array}$ & $13 \%$ & $\begin{array}{l}\text { Non-To } \\
\text { xin }\end{array}$ \\
\hline & & $\begin{array}{c}\text { HIYW } \\
\text { GKED } \\
\text { D }\end{array}$ & 48 & 56 & Outside & $\begin{array}{c}1.473 \\
3\end{array}$ & 54 & $\begin{array}{l}\text { Non } \\
\text { Allergen }\end{array}$ & $89 \%$ & $\begin{array}{l}\text { Non-To } \\
\text { xin }\end{array}$ \\
\hline & & $\begin{array}{c}\text { IYWG } \\
\text { KEDD } \\
\text { Y }\end{array}$ & 49 & 57 & Outside & $\begin{array}{c}1.472 \\
1\end{array}$ & 81 & $\begin{array}{l}\text { Non } \\
\text { Allergen }\end{array}$ & $92 \%$ & $\begin{array}{l}\text { Non-To } \\
\text { xin }\end{array}$ \\
\hline & & $\begin{array}{l}\text { MPQQ } \\
\text { LSPINI }\end{array}$ & 1 & 10 & Outside & $\begin{array}{c}1.432 \\
1\end{array}$ & 27 & $\begin{array}{l}\text { Non } \\
\text { Allergen }\end{array}$ & $65 \%$ & $\begin{array}{l}\text { Non-To } \\
\text { xin }\end{array}$ \\
\hline & & $\begin{array}{l}\text { FAIIAI } \\
\text { VFV }\end{array}$ & 15 & 23 & Outside & $\begin{array}{c}1.344 \\
4\end{array}$ & 81 & $\begin{array}{l}\text { Non } \\
\text { Allergen }\end{array}$ & $87 \%$ & $\begin{array}{l}\text { Non-To } \\
\text { xin }\end{array}$ \\
\hline & & $\begin{array}{c}\text { YWGK } \\
\text { EDDY } \\
\text { G }\end{array}$ & 50 & 58 & Outside & $\begin{array}{c}1.179 \\
8\end{array}$ & 27 & $\begin{array}{l}\text { Non } \\
\text { Allergen }\end{array}$ & $93 \%$ & $\begin{array}{l}\text { Non-To } \\
\text { xin }\end{array}$ \\
\hline & & $\begin{array}{l}\text { TFAII } \\
\text { AIVF }\end{array}$ & 14 & 22 & Outside & $\begin{array}{c}1.110 \\
5 \\
\end{array}$ & 27 & $\begin{array}{l}\text { Non } \\
\text { Allergen }\end{array}$ & $86 \%$ & $\begin{array}{l}\text { Non-To } \\
\text { xin } \\
\end{array}$ \\
\hline & & $\begin{array}{c}\text { VSDH } \\
\text { KNVY } \\
\text { F }\end{array}$ & 16 & 24 & Outside & $\begin{array}{c}1.090 \\
3\end{array}$ & 81 & $\begin{array}{l}\text { Non } \\
\text { Allergen }\end{array}$ & $71 \%$ & $\begin{array}{l}\text { Non-To } \\
\text { xin }\end{array}$ \\
\hline & & $\begin{array}{l}\text { SGEIN } \\
\text { LVHW }\end{array}$ & 69 & 77 & Outside & $\begin{array}{c}1.089 \\
5 \\
\end{array}$ & 27 & $\begin{array}{l}\text { Non } \\
\text { Allergen }\end{array}$ & $92 \%$ & $\begin{array}{l}\text { Non-To } \\
\text { xin }\end{array}$ \\
\hline & & $\begin{array}{c}\text { YWGK } \\
\text { EDDY } \\
\text { GS }\end{array}$ & 50 & 59 & Outside & $\begin{array}{c}1.073 \\
7\end{array}$ & 27 & $\begin{array}{l}\text { Non } \\
\text { Allergen }\end{array}$ & $93 \%$ & $\begin{array}{l}\text { Non-To } \\
\text { xin }\end{array}$ \\
\hline & \multirow{7}{*}{ 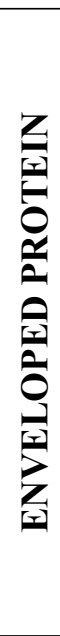 } & $\begin{array}{l}\text { FGFQA } \\
\text { EVGP }\end{array}$ & 5 & 13 & Outside & $\begin{array}{l}1.706 \\
4\end{array}$ & 81 & $\begin{array}{l}\text { Non-Aller } \\
\text { gen }\end{array}$ & $23.66 \%$ & $\begin{array}{l}\text { Non-To } \\
\text { xin }\end{array}$ \\
\hline & & $\begin{array}{l}\text { FQAEV } \\
\text { GPNN }\end{array}$ & 7 & 15 & Outside & $\begin{array}{l}1.004 \\
9\end{array}$ & 81 & $\begin{array}{l}\text { Non-Aller } \\
\text { gen }\end{array}$ & $23.66 \%$ & $\begin{array}{l}\text { Non-To } \\
\text { xin }\end{array}$ \\
\hline & & $\begin{array}{l}\text { GFQAE } \\
\text { VGPN }\end{array}$ & 6 & 14 & Outside & $\begin{array}{l}0.993 \\
1\end{array}$ & 27 & $\begin{array}{l}\text { Non-Aller } \\
\text { gen }\end{array}$ & $23.66 \%$ & $\begin{array}{l}\text { Non-To } \\
\text { xin }\end{array}$ \\
\hline & & $\begin{array}{l}\text { ASIFGF } \\
\text { QAE }\end{array}$ & 2 & 10 & Outside & $\begin{array}{l}0.666 \\
2\end{array}$ & 27 & $\begin{array}{l}\text { Non-Aller } \\
\text { gen }\end{array}$ & $21.51 \%$ & $\begin{array}{l}\text { Non-To } \\
\text { xin }\end{array}$ \\
\hline & & $\begin{array}{l}\text { SASIFG } \\
\text { FQAE }\end{array}$ & 1 & 10 & Outside & $\begin{array}{l}0.607 \\
7\end{array}$ & 27 & $\begin{array}{l}\text { Non-Aller } \\
\text { gen }\end{array}$ & $21.51 \%$ & $\begin{array}{l}\text { Non-To } \\
\text { xin }\end{array}$ \\
\hline & & $\begin{array}{l}\text { SASIFG } \\
\text { FQA }\end{array}$ & 1 & 9 & Outside & $\begin{array}{l}0.538 \\
8 \\
\end{array}$ & 27 & $\begin{array}{l}\text { Non-Aller } \\
\text { gen }\end{array}$ & $22.58 \%$ & $\begin{array}{l}\text { Non-To } \\
\text { xin }\end{array}$ \\
\hline & & $\begin{array}{l}\text { SIFGFQ } \\
\text { AEV }\end{array}$ & 3 & 11 & Outside & $\begin{array}{l}0.422 \\
7\end{array}$ & 81 & $\begin{array}{l}\text { Non-Aller } \\
\text { gen }\end{array}$ & $19.35 \%$ & $\begin{array}{l}\text { Non-To } \\
\text { xin }\end{array}$ \\
\hline & \multirow{4}{*}{  } & $\begin{array}{l}\text { GYESL } \\
\text { DLCL }\end{array}$ & 85 & 93 & Outside & $\begin{array}{l}1.275 \\
9 \\
\end{array}$ & 54 & $\begin{array}{l}\text { Non-Aller } \\
\text { gen }\end{array}$ & $72 \%$ & $\begin{array}{l}\text { Non-To } \\
\text { xin }\end{array}$ \\
\hline & & $\begin{array}{l}\text { IGFTV } \\
\text { GHDY }\end{array}$ & 29 & 37 & Outside & $\begin{array}{l}1.253 \\
7\end{array}$ & 81 & $\begin{array}{l}\text { Non-Aller } \\
\text { gen }\end{array}$ & $23 \%$ & $\begin{array}{l}\text { Non-To } \\
\text { xin }\end{array}$ \\
\hline & & $\begin{array}{l}\text { YDHLN } \\
\text { VVNG }\end{array}$ & 102 & $\begin{array}{l}11 \\
0\end{array}$ & Outside & $\begin{array}{l}1.100 \\
4\end{array}$ & 54 & $\begin{array}{l}\text { Non-Aller } \\
\text { gen }\end{array}$ & $12 \%$ & $\begin{array}{l}\text { Non-To } \\
\text { xin }\end{array}$ \\
\hline & & $\begin{array}{l}\text { NYYAL } \\
\text { SGIG }\end{array}$ & 77 & 85 & Outside & $\begin{array}{l}1.089 \\
9\end{array}$ & 27 & $\begin{array}{l}\text { Non-Aller } \\
\text { gen }\end{array}$ & $83 \%$ & $\begin{array}{l}\text { Non-To } \\
\text { xin }\end{array}$ \\
\hline
\end{tabular}




\begin{tabular}{|c|c|c|c|c|c|c|c|c|c|c|}
\hline & & $\begin{array}{l}\text { YALSG } \\
\text { IGYE }\end{array}$ & 79 & 87 & Outside & $\begin{array}{l}1.067 \\
8\end{array}$ & 27 & $\begin{array}{l}\text { Non-Aller } \\
\text { gen }\end{array}$ & $85 \%$ & $\begin{array}{l}\text { Non-To } \\
\text { xin }\end{array}$ \\
\hline & & $\begin{array}{l}\text { TKGGY } \\
\text { LFIG }\end{array}$ & 12 & 20 & Outside & $\begin{array}{l}1.066 \\
7\end{array}$ & 27 & $\begin{array}{l}\text { Non-Aller } \\
\text { gen }\end{array}$ & $20 \%$ & $\begin{array}{l}\text { Non-To } \\
\text { xin }\end{array}$ \\
\hline & & $\begin{array}{l}\text { NYYAL } \\
\text { SGIGY }\end{array}$ & 77 & 86 & Outside & 1.04 & 27 & $\begin{array}{l}\text { Non-Aller } \\
\text { gen }\end{array}$ & $82 \%$ & $\begin{array}{l}\text { Non-To } \\
\text { xin }\end{array}$ \\
\hline & & $\begin{array}{l}\text { GGGTI } \\
\text { EVTS }\end{array}$ & 70 & 78 & Outside & $\begin{array}{l}1.036 \\
9 \\
\end{array}$ & 27 & $\begin{array}{l}\text { Non-Aller } \\
\text { gen }\end{array}$ & $59 \%$ & $\begin{array}{l}\text { Non-To } \\
\text { xin }\end{array}$ \\
\hline & & $\begin{array}{l}\text { YYALS } \\
\text { GIGY }\end{array}$ & 78 & 86 & Outside & $\begin{array}{l}1.022 \\
9\end{array}$ & 54 & $\begin{array}{l}\text { Non-Aller } \\
\text { gen }\end{array}$ & $85 \%$ & $\begin{array}{l}\text { Non-To } \\
\text { xin }\end{array}$ \\
\hline & & $\begin{array}{l}\text { SGGGT } \\
\text { IEVT }\end{array}$ & 67 & 77 & Outside & $\begin{array}{l}1.000 \\
1\end{array}$ & 27 & $\begin{array}{l}\text { Non-Aller } \\
\text { gen }\end{array}$ & $60 \%$ & $\begin{array}{l}\text { Non-To } \\
\text { xin }\end{array}$ \\
\hline \multirow{12}{*}{ 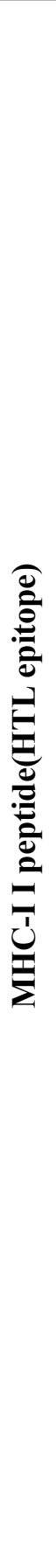 } & \multirow{10}{*}{ 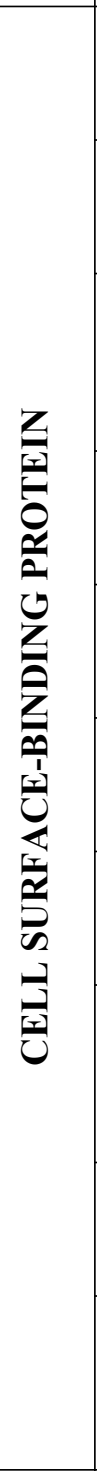 } & $\begin{array}{l}\text { MPQQL } \\
\text { SPINIE } \\
\text { TKKA }\end{array}$ & 1 & 15 & Outside & $\begin{array}{l}1.345 \\
2\end{array}$ & 27 & $\begin{array}{l}\text { Non Non- } \\
\text { Allergen }\end{array}$ & $65 \%$ & $\begin{array}{l}\text { Non-To } \\
\text { xin }\end{array}$ \\
\hline & & $\begin{array}{l}\text { PQQLS } \\
\text { PINIET } \\
\text { KKAI }\end{array}$ & 2 & 16 & Outside & $\begin{array}{l}1.282 \\
4\end{array}$ & 27 & $\begin{array}{l}\text { Non } \\
\text { Allergen }\end{array}$ & $65 \%$ & $\begin{array}{l}\text { Non-To } \\
\text { xin }\end{array}$ \\
\hline & & $\begin{array}{l}\text { EYVLS } \\
\text { TIHIY } \\
\text { WGKE } \\
\text { D }\end{array}$ & 41 & 55 & Outside & $\begin{array}{l}1.064 \\
9 \\
\end{array}$ & 27 & $\begin{array}{l}\text { Non } \\
\text { Allergen }\end{array}$ & $13 \%$ & $\begin{array}{l}\text { Non-To } \\
\text { xin }\end{array}$ \\
\hline & & $\begin{array}{l}\text { INFKG } \\
\text { GYISG } \\
\text { GFLPN }\end{array}$ & 26 & 40 & Outside & $\begin{array}{l}1.012 \\
5\end{array}$ & 27 & $\begin{array}{l}\text { Non } \\
\text { Allergen }\end{array}$ & $86 \%$ & $\begin{array}{l}\text { Non-To } \\
\text { xin }\end{array}$ \\
\hline & & $\begin{array}{l}\text { IEGNK } \\
\text { TFAIIAI } \\
\text { VFV }\end{array}$ & 9 & 23 & Outside & $\begin{array}{l}0.837 \\
4\end{array}$ & 27 & $\begin{array}{l}\text { Non } \\
\text { Allergen }\end{array}$ & $72 \%$ & $\begin{array}{l}\text { Non-To } \\
\text { xin }\end{array}$ \\
\hline & & $\begin{array}{l}\text { NFKGG } \\
\text { YISGGF } \\
\text { LPNE }\end{array}$ & 27 & 41 & Outside & $\begin{array}{l}0.796 \\
5\end{array}$ & 27 & $\begin{array}{l}\text { Non } \\
\text { Allergen }\end{array}$ & $86 \%$ & $\begin{array}{l}\text { Non-To } \\
\text { xin }\end{array}$ \\
\hline & & $\begin{array}{l}\text { KTFAII } \\
\text { AIVFVF } \\
\text { ILT }\end{array}$ & 13 & 27 & Outside & $\begin{array}{l}0.761 \\
8\end{array}$ & 27 & $\begin{array}{l}\text { Non } \\
\text { Allergen }\end{array}$ & $82 \%$ & $\begin{array}{l}\text { Non-To } \\
\text { xin }\end{array}$ \\
\hline & & $\begin{array}{l}\text { WGKE } \\
\text { DDYGS } \\
\text { NHLID } \\
\text { V }\end{array}$ & 51 & 65 & Outside & $\begin{array}{l}0.760 \\
7 \\
\end{array}$ & 27 & $\begin{array}{l}\text { Non } \\
\text { Allergen }\end{array}$ & $91 \%$ & $\begin{array}{l}\text { Non-To } \\
\text { xin }\end{array}$ \\
\hline & & $\begin{array}{l}\text { IAIFLQ } \\
\text { VSDHK } \\
\text { NVYF }\end{array}$ & 10 & 24 & Outside & $\begin{array}{l}0.733 \\
7\end{array}$ & 27 & $\begin{array}{l}\text { Non } \\
\text { Allergen }\end{array}$ & $8 \%$ & $\begin{array}{l}\text { Non-To } \\
\text { xin }\end{array}$ \\
\hline & & $\begin{array}{l}\text { TLDYF } \\
\text { TYLGT } \\
\text { TINHS }\end{array}$ & 56 & 70 & Outside & $\begin{array}{l}0.713 \\
3\end{array}$ & 27 & $\begin{array}{l}\text { Non } \\
\text { Allergen }\end{array}$ & $48 \%$ & $\begin{array}{l}\text { Non-To } \\
\text { xin }\end{array}$ \\
\hline & \multirow{2}{*}{ 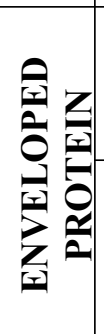 } & $\begin{array}{l}\text { SASIFG } \\
\text { FQAEV } \\
\text { GPNN }\end{array}$ & 1 & 15 & Outside & $\begin{array}{l}0.745 \\
3\end{array}$ & 27 & $\begin{array}{l}\text { Non-Aller } \\
\text { gen }\end{array}$ & $18.28 \%$ & $\begin{array}{l}\text { Non-To } \\
\text { xin }\end{array}$ \\
\hline & & $\begin{array}{l}\text { ASIFGF } \\
\text { QAEVG } \\
\text { PNNT }\end{array}$ & 2 & 16 & Outside & $\begin{array}{l}0.791 \\
1\end{array}$ & 27 & $\begin{array}{l}\text { Non-Aller } \\
\text { gen }\end{array}$ & $18.28 \%$ & $\begin{array}{l}\text { Non-To } \\
\text { xin }\end{array}$ \\
\hline
\end{tabular}




\begin{tabular}{|c|c|c|c|c|c|c|c|c|c|}
\hline \multirow{10}{*}{ 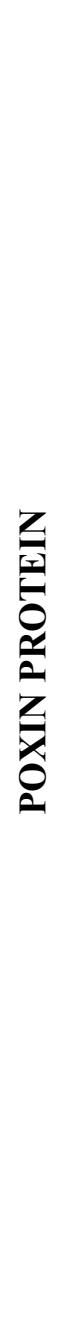 } & $\begin{array}{l}\text { NYYAL } \\
\text { SGIGY } \\
\text { ESLDL } \\
\end{array}$ & 77 & 91 & Outside & 1.338 & 27 & $\begin{array}{l}\text { Non } \\
\text { Allergen }\end{array}$ & $72 \%$ & $\begin{array}{l}\text { Non-To } \\
\text { xin }\end{array}$ \\
\hline & $\begin{array}{l}\text { YYALS } \\
\text { GIGYE } \\
\text { SLDLC }\end{array}$ & 78 & 92 & Outside & 1.091 & 27 & $\begin{array}{l}\text { Non-Aller } \\
\text { gen }\end{array}$ & $72 \%$ & $\begin{array}{l}\text { Non-To } \\
\text { xin }\end{array}$ \\
\hline & $\begin{array}{l}\text { SGGGT } \\
\text { IEVTSK } \\
\text { EERV }\end{array}$ & 69 & 73 & Outside & $\begin{array}{l}1.087 \\
6\end{array}$ & 27 & $\begin{array}{l}\text { Non-Aller } \\
\text { gen }\end{array}$ & $44 \%$ & $\begin{array}{l}\text { Non-To } \\
\text { xin }\end{array}$ \\
\hline & $\begin{array}{l}\text { LNSGG } \\
\text { GTIEVT } \\
\text { SKEE }\end{array}$ & 67 & 81 & Outside & $\begin{array}{l}1.063 \\
9\end{array}$ & 27 & $\begin{array}{l}\text { Non } \\
\text { Allergen }\end{array}$ & $45 \%$ & $\begin{array}{l}\text { Non-To } \\
\text { xin }\end{array}$ \\
\hline & $\begin{array}{l}\text { SFANT } \\
\text { KGGYL } \\
\text { FIGVD }\end{array}$ & 8 & 22 & Outside & $\begin{array}{l}0.979 \\
5\end{array}$ & 27 & $\begin{array}{l}\text { Non-Aller } \\
\text { gen }\end{array}$ & $12 \%$ & $\begin{array}{l}\text { Non-To } \\
\text { xin }\end{array}$ \\
\hline & $\begin{array}{l}\text { SSFAN } \\
\text { TKGGY } \\
\text { LFIGV }\end{array}$ & 7 & 21 & Outside & $\begin{array}{l}0.929 \\
1\end{array}$ & 27 & $\begin{array}{l}\text { Non-Aller } \\
\text { gen }\end{array}$ & $12 \%$ & $\begin{array}{l}\text { Non-To } \\
\text { xin }\end{array}$ \\
\hline & $\begin{array}{l}\text { VYDHL } \\
\text { NVVNG } \\
\text { EERCY }\end{array}$ & 101 & $\begin{array}{l}11 \\
5\end{array}$ & Outside & $\begin{array}{l}0.928 \\
8\end{array}$ & 27 & $\begin{array}{l}\text { Non } \\
\text { Allergen }\end{array}$ & $11 \%$ & $\begin{array}{l}\text { Non-To } \\
\text { xin }\end{array}$ \\
\hline & $\begin{array}{l}\text { LLNSG } \\
\text { GGTIE } \\
\text { VTSKE }\end{array}$ & 66 & 80 & Outside & $\begin{array}{l}0.821 \\
8\end{array}$ & 27 & $\begin{array}{l}\text { Non } \\
\text { Allergen }\end{array}$ & $45 \%$ & $\begin{array}{l}\text { Non-To } \\
\text { xin }\end{array}$ \\
\hline & $\begin{array}{l}\text { KRGAV } \\
\text { LPIPNL } \\
\text { VKVK }\end{array}$ & 35 & 49 & Outside & $\begin{array}{l}0.788 \\
5\end{array}$ & 27 & $\begin{array}{l}\text { Non-Aller } \\
\text { gen }\end{array}$ & $26 \%$ & $\begin{array}{l}\text { Non-To } \\
\text { xin }\end{array}$ \\
\hline & $\begin{array}{l}\text { ALLPM } \\
\text { FECNE } \\
\text { YLQIG }\end{array}$ & 43 & 57 & Outside & 0.781 & 27 & $\begin{array}{l}\text { Non-Aller } \\
\text { gen }\end{array}$ & $78 \%$ & $\begin{array}{l}\text { Non-To } \\
\text { xin }\end{array}$ \\
\hline
\end{tabular}


Table 04: Allergenicity assessment antigenicity investigation of the anticipated B-cell epitopes

\begin{tabular}{|c|c|c|c|c|}
\hline $\begin{array}{c}\text { Protei } \\
\text { n }\end{array}$ & Algorithm & Top Epitope & Allergenicity & $\begin{array}{c}\text { VaxiJen } \\
\text { score }\end{array}$ \\
\hline \multirow{3}{*}{ 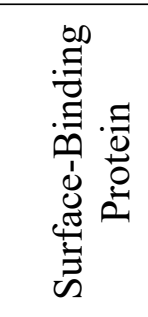 } & Linear epitope & $\begin{array}{c}\text { KYSGEINLVHWNKKKYS } \\
\text { SYEEKKHDDG }\end{array}$ & Non-allergen & 0.8238 \\
\hline & $\begin{array}{c}\text { Surface } \\
\text { accessibility }\end{array}$ & HYNESKPTTI & Non-allergen & 0.5181 \\
\hline & Antigenicity & HKNVYFQKIVNQL & Non-allergen & -0.0446 \\
\hline \multirow{3}{*}{ 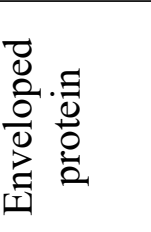 } & Linear epitope & GFQAEVG & Non-allergen & 0.5058 \\
\hline & $\begin{array}{c}\text { Surface } \\
\text { accessibility }\end{array}$ & VGPNNT & Non-allergen & 1.2433 \\
\hline & Antigenicity & IFGFQAE & Non-allergen & 0.7731 \\
\hline \multirow{3}{*}{ 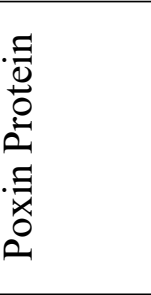 } & Linear epitope & DYHVWIGDCVCQVTTVD & Non-allergen & 0.3489 \\
\hline & $\begin{array}{c}\text { Surface } \\
\text { accessibility }\end{array}$ & $\begin{array}{c}\text { KVQHEYSTIKEKAKEMN } \\
\text { AK }\end{array}$ & Non-allergen & 0.8280 \\
\hline & Antigenicity & GAVLPIPNLVKVK & Non-allergen & 0.4370 \\
\hline
\end{tabular}


Table 05: Allergenicity, antienicity and solubility prediction of the designed vaccine constructs

\begin{tabular}{|c|c|c|c|c|c|}
\hline $\begin{array}{c}\text { Vaccine } \\
\text { Constr } \\
\text { ucts }\end{array}$ & Composition & Complete Sequence of Vaccine Construct & $\begin{array}{c}\text { Allergenecit } \\
\mathbf{y}\end{array}$ & $\begin{array}{c}\text { Vaxijen } \\
\text { Score } \\
\text { (Antigenecit } \\
\text { y) } \\
\text { Threshold } \\
0.4\end{array}$ & $\begin{array}{c}\text { Solubilit } \\
\mathbf{y}\end{array}$ \\
\hline V1 & $\begin{array}{l}\text { Predicted CTL, } \\
\text { HTL \& BCL } \\
\text { epitopes with } \\
\text { defensin } \\
\text { adjuvant } \\
\text { and PADRE } \\
\text { sequence }\end{array}$ & $\begin{array}{l}\text { EAAAKGIINTLQKYYCRVRGGRCAVLSCLPKE } \\
\text { EQIGKCSTRGRKCCRRKKEAAAKAKFVAAWT } \\
\text { LKAAAGGGSIYWGKEDDYGGGSFGFQAEVGP } \\
\text { GGGSNYYALSGIGGPGPGINFKGGYISGGFLPN } \\
\text { GPGPGASIFGFQAEVGPNNTGPGPGNYYALSG } \\
\text { IGYESLDLKKKYSGEINLVHWNKKKYSSYEEK } \\
\text { KHDDGKKHYNESKPTTIKKHKNVYFQKIVNQL } \\
\text { KKGFQAEVGKKVGPNNTKKIFGFQAEKKDYH } \\
\text { VWIGDCVCQVTTVDKKKVQHEYSTIKEKAKE } \\
\text { MNAKKKGAVLPIPNLVKVKKKAKFVAAWTLK } \\
\text { AAAGGGS }\end{array}$ & $\begin{array}{c}\text { Probable } \\
\text { non-allergen }\end{array}$ & 0.6547 & 0.657 \\
\hline V2 & $\begin{array}{l}\text { Predicted CTL, } \\
\text { HTL \& BCL } \\
\text { epitopes with } \\
\text { L7/L12 } \\
\text { ribosomal } \\
\text { protein } \\
\text { adjuvant \& } \\
\text { PADRE } \\
\text { sequence }\end{array}$ & $\begin{array}{l}\text { EAAKMAKLSTDELLDAFKEMTLLELSDFVKKF } \\
\text { EETFEVTAAAPVAVAAAGAAPAGAAVEAAEE } \\
\text { QSEFDVILEAAGDKKIGVIKVVREIVSGLGLKEA } \\
\text { KDLVDGAPKPLLEKVAKEAADEAKAKLEAAG } \\
\text { ATVTVKEAAAKAKFVAAWTLKAAAGGGSIY } \\
\text { WGKEDDYGGGSFGFQAEVGPGGGSNYYALSG } \\
\text { IGGPGPGINFKGGYISGGFLPNGPGPGASIFGFQ } \\
\text { AEVGPNNTGPGPGNYYALSGIGYESLDLKKKY } \\
\text { SGEINLVHWNKKKYSSYEEKKHDDGKKHYNE } \\
\text { SKPTTIKKHKNVYFQKIVNQLKKGFQAEVGKK } \\
\text { VGPNNTKKIFGFQAEKKDYHVWIGDCVCQVT } \\
\text { TVDKKKVQHEYSTIKEKAKEMNAKKKGAVLP } \\
\text { IPNLVKVKKKAKFVAAWTLKAAAGGGS }\end{array}$ & $\begin{array}{c}\text { Probable } \\
\text { non-allergen }\end{array}$ & 0.5843 & 0.590 \\
\hline V3 & $\begin{array}{c}\text { Predicted CTL, } \\
\text { HTL \& BCL } \\
\text { epitopes with } \\
\text { HABA } \\
\text { adjuvant \& } \\
\text { PADRE } \\
\text { sequence }\end{array}$ & $\begin{array}{l}\text { EAAKMAENPNIDDLPAPLLAALGAADLALATV } \\
\text { NDLIANLRERAEETRAETRTRVEERRARLTKFQ } \\
\text { EDLPEQFIELRDKFTTEELRKAAEGYLEAATNR } \\
\text { YNELVERGEAALQRLRSQTAFEDASARAEGYV } \\
\text { DQAVELTQEALGTVASQTRAVGERAAKLVGIE } \\
\text { LEAAAKAKFVAAWTLKAAAGGGSAEAAAKA } \\
\text { KFVAAWTLKAAAGGGSIYWGKEDDYGGGSF } \\
\text { GFQAEVGPGGGSNYYALSGIGGPGPGINFKGG } \\
\text { YISGGFLPNGPGPGASIFGFQAEVGPNNTGPGP } \\
\text { GNYYALSGIGYESLDLKKKYSGEINLVHWNKK } \\
\text { KYSSYEEKKHDDGKKHYNESKPTTIKKHKNV } \\
\text { YFQKIVNQLKKGFQAEVGKKVGPNNTKKIFGF } \\
\text { QAEKKDYHVWIGDCVCQVTTVDKKKVQHEY } \\
\text { STIKEKAKEMNAKKKGAVLPIPNLVKVKKKAK } \\
\text { FVAAWTLKAAAGGGS }\end{array}$ & $\begin{array}{c}\text { Probable } \\
\text { non-allergen }\end{array}$ & 0.6122 & 5.5 \\
\hline
\end{tabular}


Table 06: Docking scores of vaccine constracts with different HLA alleles i. e. HLA-DRB1*03:01 (1a6a), HLA-DRB5*01:01 (1h15), HLA-DRB1*01:01 (2fse), HLA-DRB3*01:01 (2q6w), HLA-DRB1*04:01(2seb) and HLA-DRB3*02:02 (3c5j) and TLR 2, TLR 4,TLR 9

\begin{tabular}{|c|c|c|c|c|c|c|}
\hline $\begin{array}{l}\text { Vaccine } \\
\text { constru } \\
\text { ct }\end{array}$ & $\begin{array}{l}\text { HLA } \\
\text { alleles } \\
\text { PDB } \\
\text { ID's }\end{array}$ & $\begin{array}{l}\text { Global } \\
\text { Energy }\end{array}$ & $\begin{array}{l}\text { Hydrog } \\
\text { en bond } \\
\text { energy }\end{array}$ & ACE & Score & Area \\
\hline \multirow[t]{6}{*}{ V1 } & 1a6a & -34.21 & -2.33 & -1.21 & 13550 & 1718.30 \\
\hline & $1 \mathrm{~h} 15$ & -15.11 & -5.47 & 8.40 & 15484 & 2032.20 \\
\hline & $2 \mathrm{fse}$ & -35.94 & -6.33 & -1.47 & 15238 & 2578.00 \\
\hline & $2 q 6 w$ & -34.21 & -2.33 & -1.21 & 13550 & 1718.30 \\
\hline & $2 \mathrm{seb}$ & -26.09 & -2.25 & -2.92 & 15120 & 1819.50 \\
\hline & $3 \mathrm{c} 5 \mathrm{j}$ & -31.61 & -3.93 & -1.27 & 15712 & 2028.90 \\
\hline \multirow[t]{6}{*}{ V2 } & 1a6a & -11.98 & -9.71 & -0.70 & 19082 & 2680.10 \\
\hline & 1h15 & 8.72 & 0.00 & -0.44 & 17680 & 2621.30 \\
\hline & $2 \mathrm{fse}$ & 0.00 & 0.00 & 0.00 & 18078 & 2799.70 \\
\hline & $2 q 6 w$ & 3.07 & 0.00 & 3.48 & 17258 & 2302.80 \\
\hline & $2 \mathrm{seb}$ & -19.73 & -4.91 & -0.36 & 21592 & 3036.00 \\
\hline & $3 \mathrm{c} 5 \mathrm{j}$ & -13.29 & -3.60 & 12.14 & 20484 & 3360.20 \\
\hline \multirow[t]{6}{*}{ V3 } & 1a6a & 0.30 & -4.84 & 1.42 & 17434 & 2319.20 \\
\hline & 1h15 & -21.55 & -3.68 & 15.24 & 17008 & 2435.50 \\
\hline & $2 \mathrm{fse}$ & 2.14 & -1.00 & 4.96 & 15978 & 3697.00 \\
\hline & $2 q 6 w$ & -23.89 & $\begin{array}{l}-0.57 \\
\end{array}$ & -5.54 & 19066 & 2660.10 \\
\hline & $2 \mathrm{seb}$ & -30.10 & -2.08 & -6.81 & 16648 & 2406.30 \\
\hline & $3 \mathrm{c} 5 \mathrm{j}$ & -32.99 & -2.06 & 3.20 & 16214 & 2755.50 \\
\hline \multirow[t]{4}{*}{ V1 } & $2 \mathrm{z} 5 \mathrm{v}$ & -17.68 & -2.79 & 3.34 & 12824 & 1596.90 \\
\hline & 1 fyw & -7.36 & -1.87 & 3.68 & 15136 & 2882.00 \\
\hline & 5D67 & -32.77 & -6.92 & -0.78 & 18654 & 2631.20 \\
\hline & $3 \mathrm{w} 3 \mathrm{k}$ & -12.24 & -3.65 & 12.22 & 19024 & 3013.00 \\
\hline
\end{tabular}




\section{Figure Legends}

Figure 01: Schematic representation of the process used for epitope based vaccine developent against monkeypox virus.

Figure 02: Population coverage analysis of predicted T-cell epitopes (MHC-I and MHC-II peptides) for Cell surface binding protein (a); Envelope protein (b)and Poxin-Schlafen (c).

Figure 03: Solubility prediction of designed superior vaccine V1 using via Protein-sol server.

Figure 04: Tertiary structure of vaccine construct V1(a) and validation of it's tertiary structure via by Ramachandran plot analysis (b).

Figure 05: Tertiary structure of V2 (a) and V3 (b)vaccine constructs.

Figure 06: Disulfied engineering of predicted superior vaccine construct V1; original (a) and mutant (b).

Figure 07: Molecular docking between vaccine V1 with MyD88 (a), TLR2 (b) and TLR8 (c).

Figure 08: Restriction digestion and in silico cloning of the gene sequence of final construct V1 into pET28a $(+)$ expression vector. Target sequence was inserted between BgIII (401) and BGII (2187). 
Retrival of Monkeypox proteome

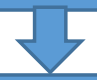

Antigenecity testing of possible candidates

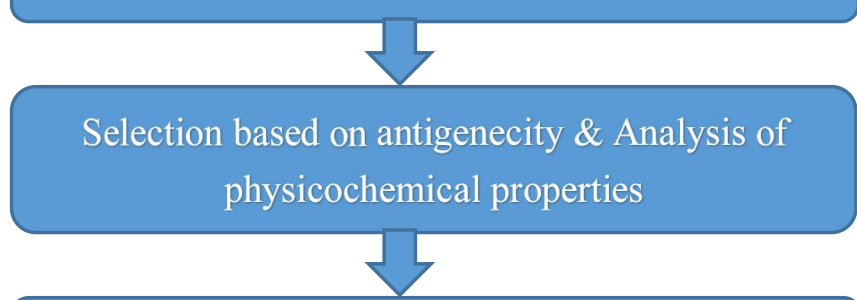

Conserved regions selection of three proteins



T cell epitope predictions for

conserved regions

\section{एᄂ}

Transmembrane topology and antigenecity prediction

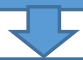

Population coverage, allergenecity and toxicity scoring of possible epitopes

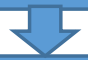

Conservency analysis of possible epitopes

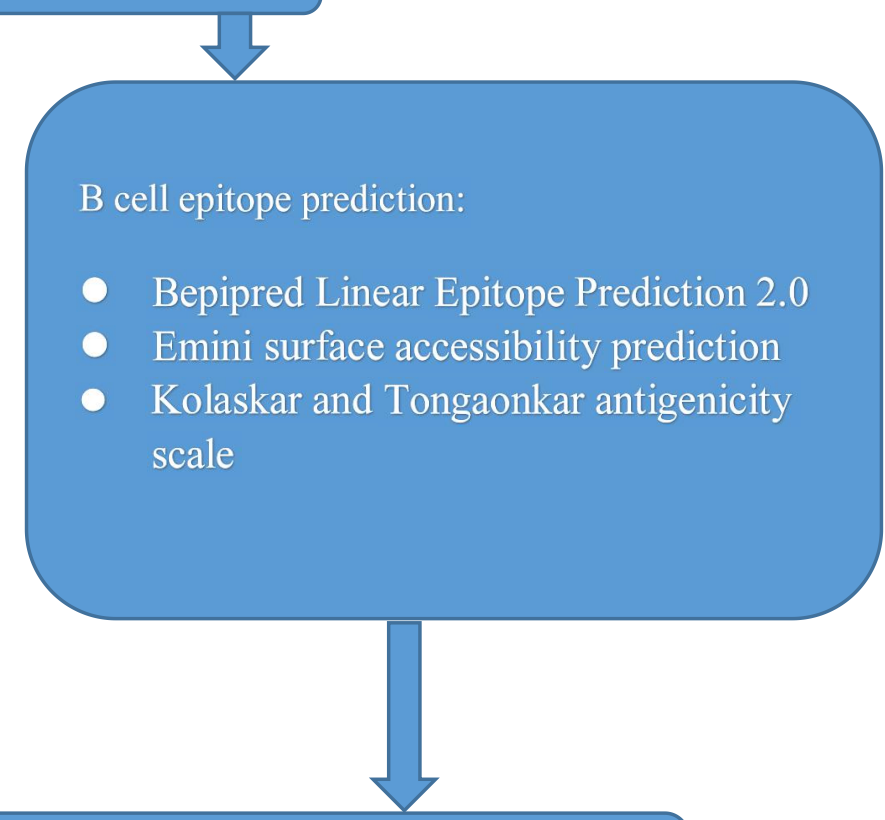

Vaccines construction using selected epitopes, PADRE sequence and different linkers

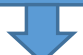

Best construct selection based on antigenecity, allergenecity and solubility

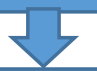

Analysis of physicochemical properties and secondary structure of selected construct



3D structure prediction, validation and disulfide engineering of the construct

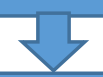

Protein-protein docking

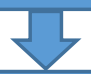

Codon adaptation and in silico cloning

Figure 01: Schematic representation of the process used for epitope based vaccine developent against monkeypox virus. 


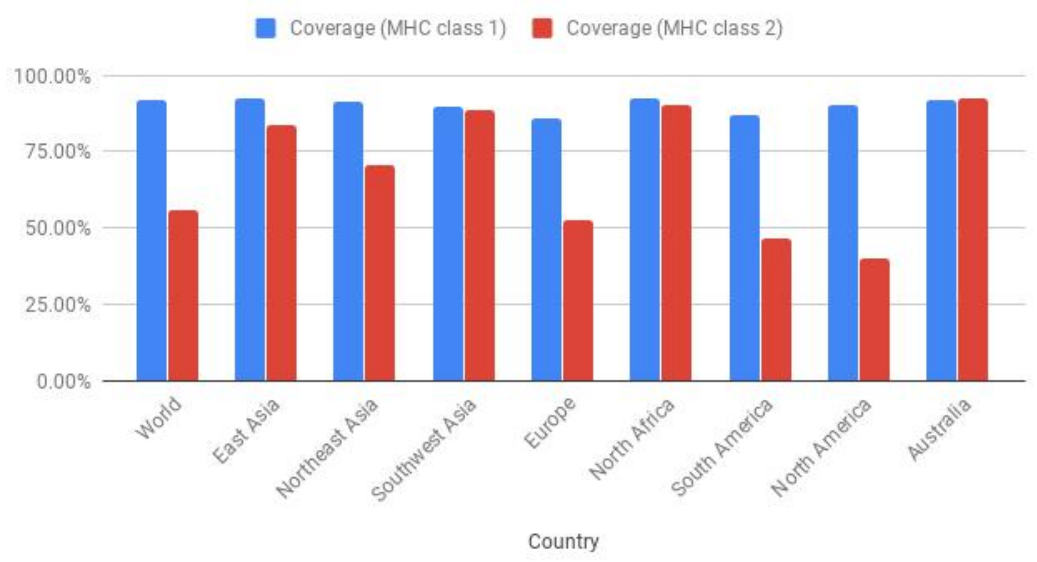

(a)

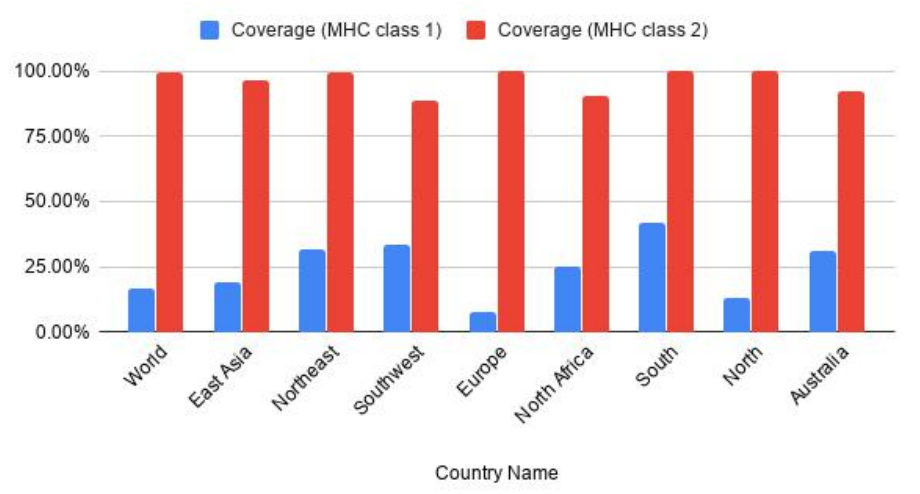

(b)



(c)

Figure 02: Population coverage analysis of predicted T-cell epitopes (MHC-I and MHC-II peptides) for Cell surface binding protein (a); Envelope protein (b) and Poxin-Schlafen (c). 


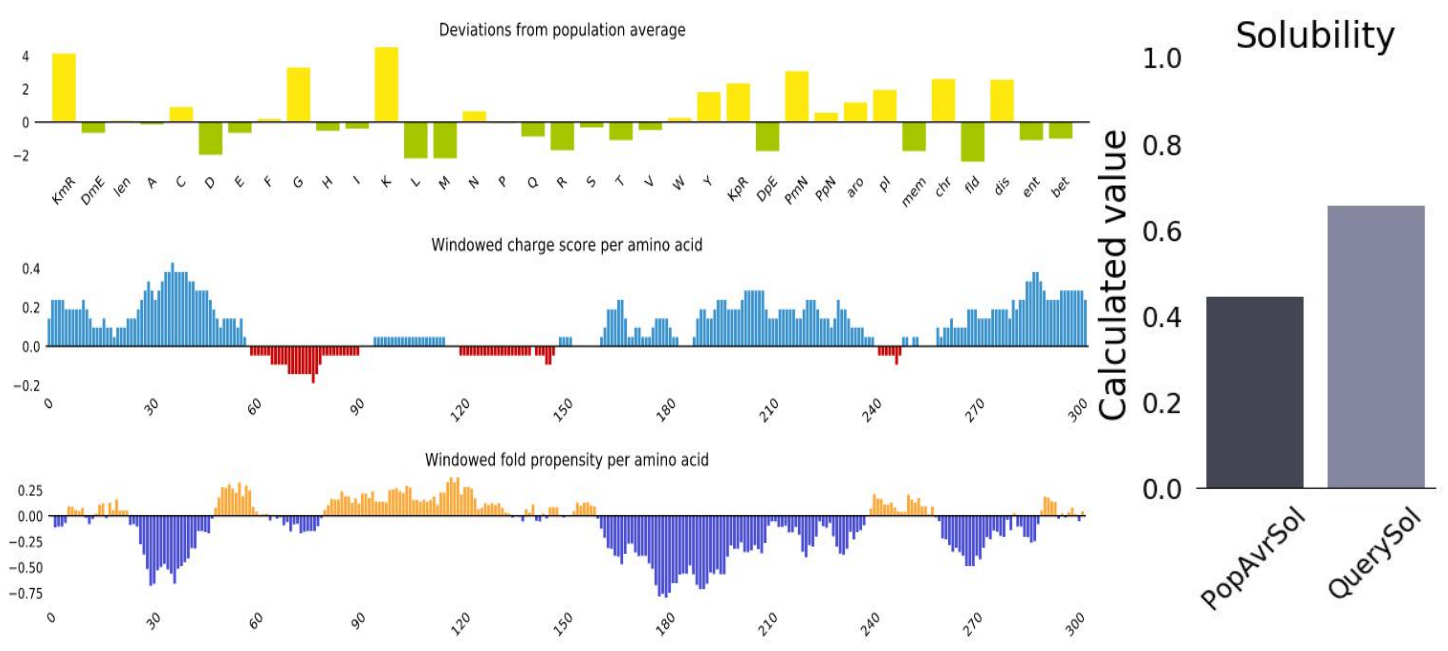

Figure 03: Solubility prediction of designed superior vaccine V1 using via Protein-sol server.

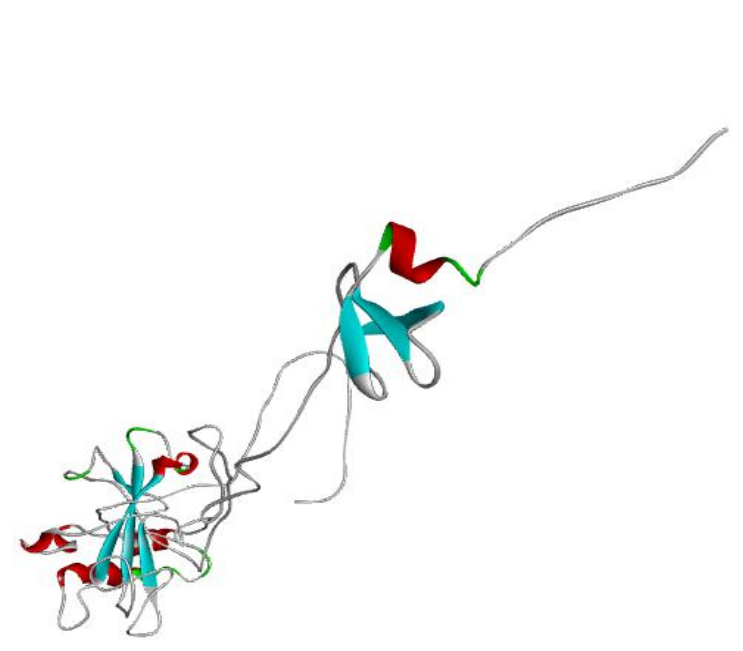

(a)

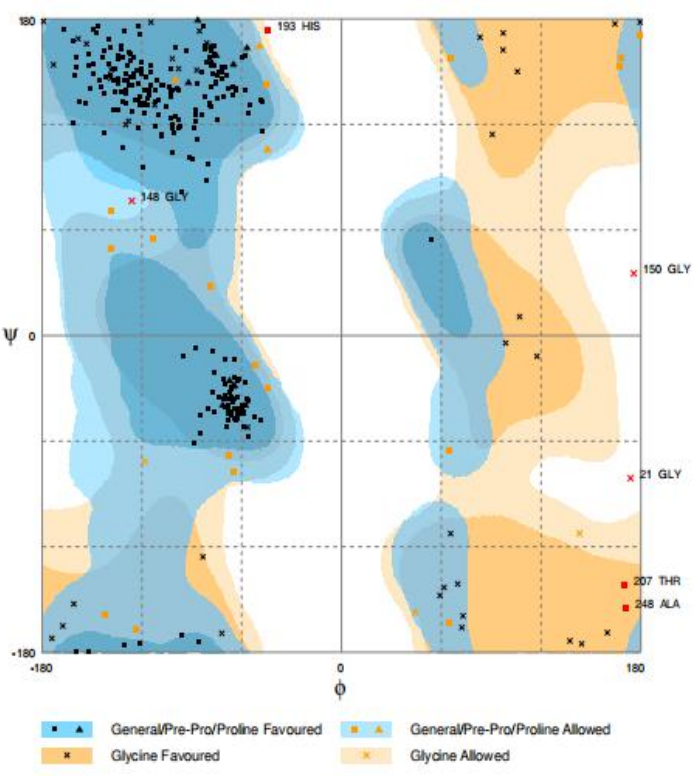

(b)

4(b)

Figure 04: Tertiary structure of vaccine construct V1(a) and validation of it's tertiary structure via by Ramachandran plot analysis (b). 


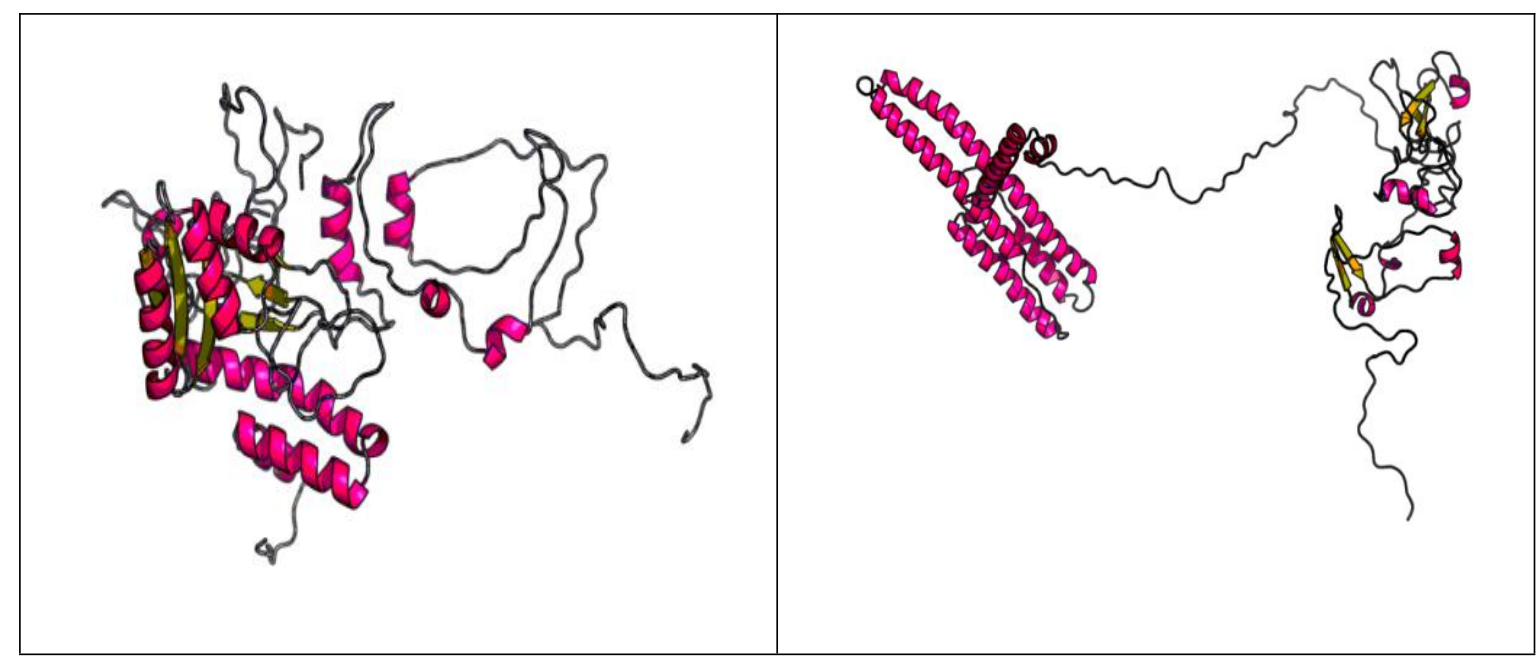

(a)

(b)

Figure 05: Tertiary structure of V2 (a) and V3 (b)vaccine constructs.

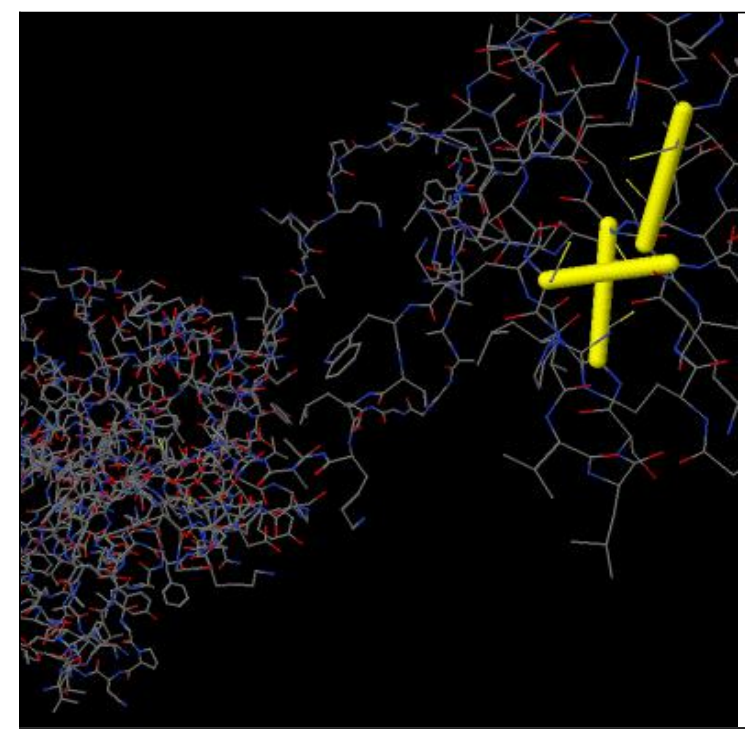

(a)

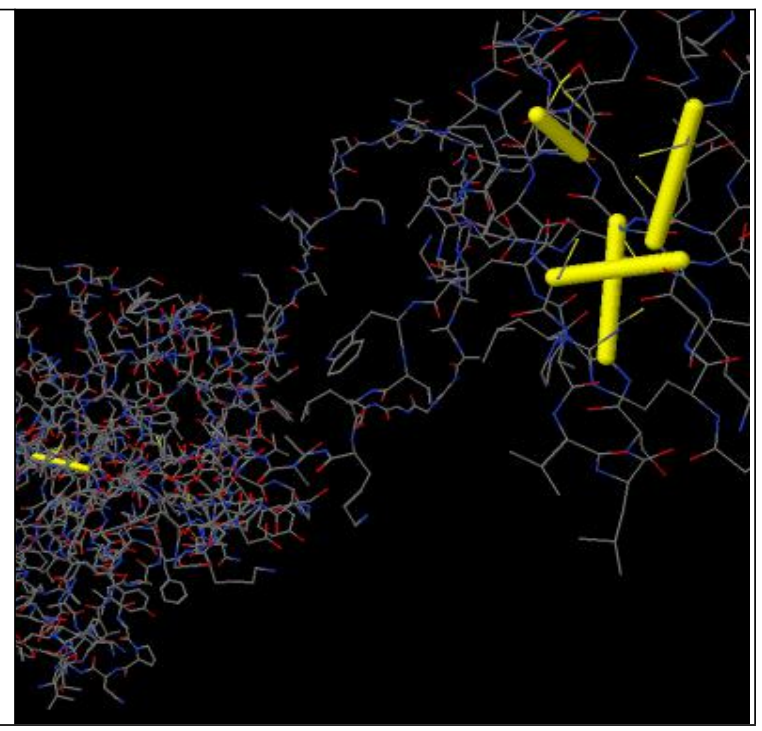

(b)

Figure 06: Disulfied engineering of predicted superior vaccine construct V1; original (a) and mutant (b). 

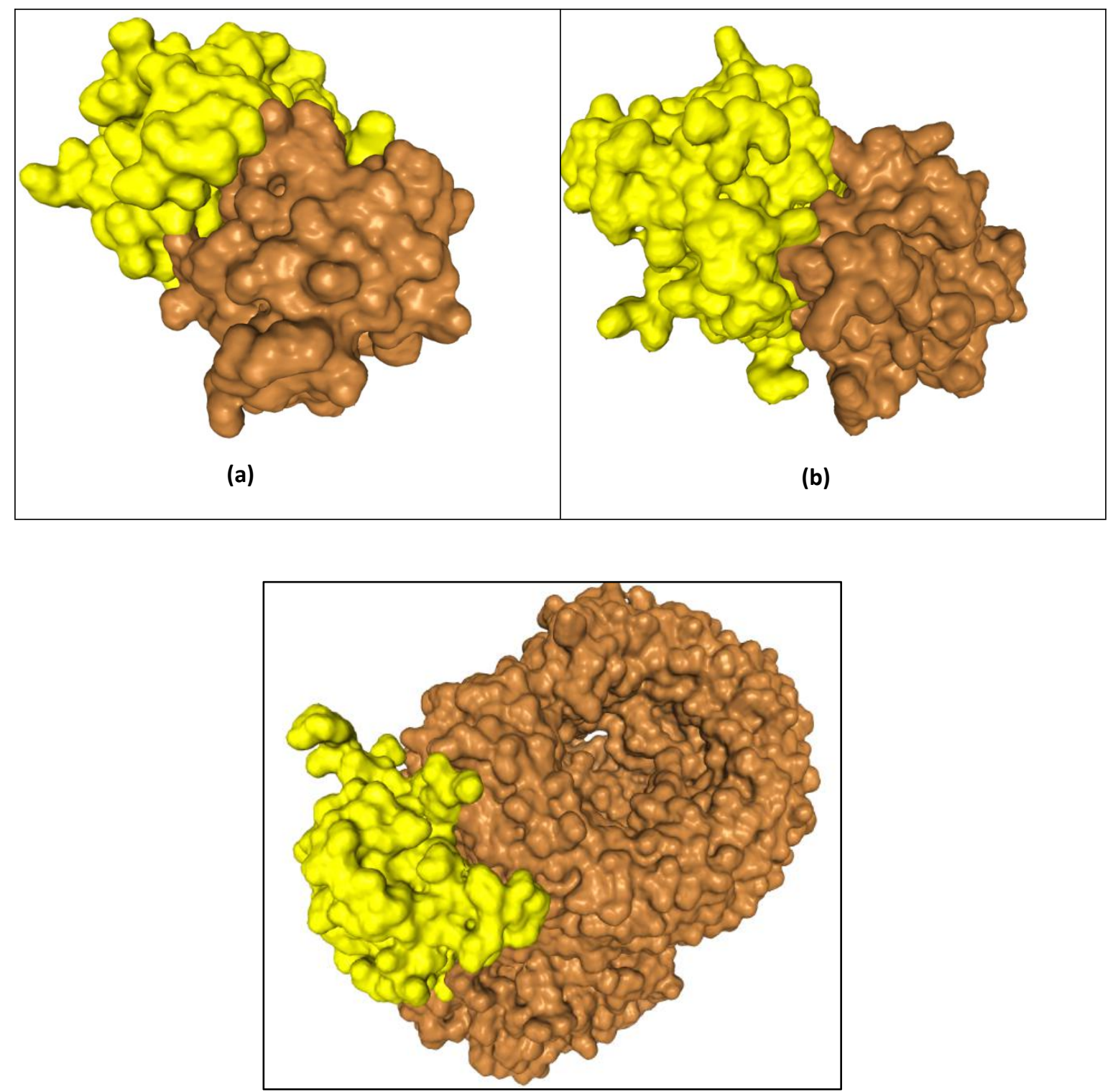

(c)

Figure 7: Molecular docking between vaccine V1 with MyD88 (a), TLR2 (b) and TLR8 (c). 


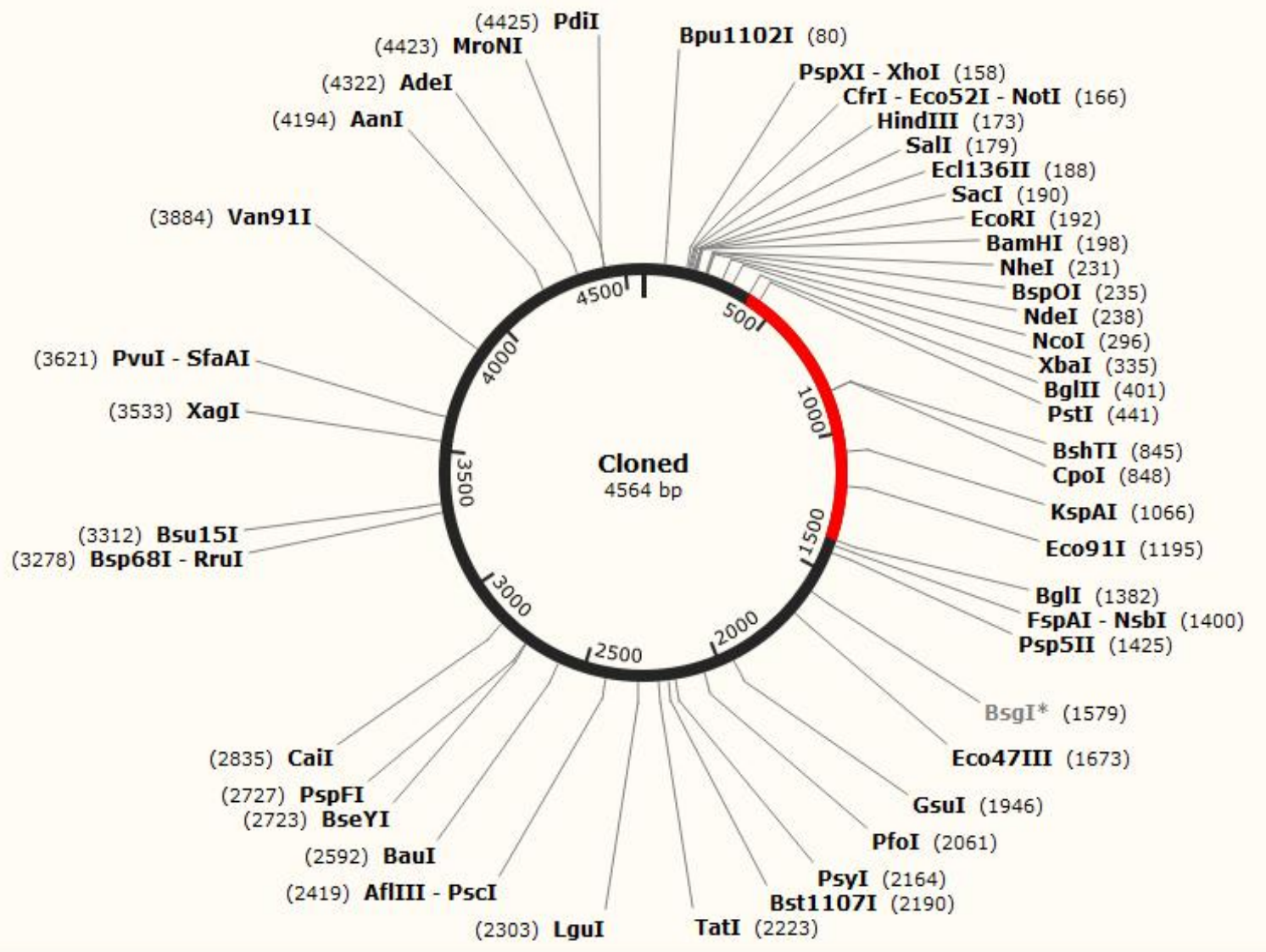

(a)

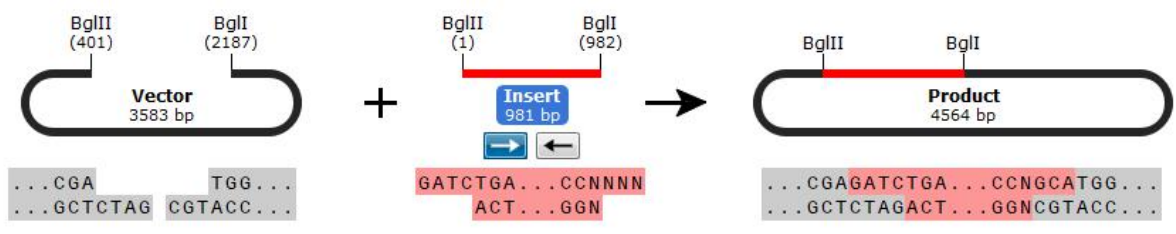

(b)

Figure 08: Restriction digestion and in silico cloning of the gene sequence of final construct V1 into pET28a(+) expression vector. Target sequence was inserted between BgIII (401) and BGII (2187). 